\title{
Synthesis
}

\section{Cultural Ecosystem Services: A Literature Review and Prospects for Future Research}

$\underline{\text { Andra Ioana Milcu }}^{1}$, Jan Hanspach $^{1}$, David Abson $^{2}$ and Joern Fischer ${ }^{1}$

\begin{abstract}
Cultural ecosystem services constitute a growing field of research that is characterized by an increasing number of publications from various academic disciplines. We conducted a semiquantitative review of publications explicitly dealing with cultural ecosystem services. Our aims were: (1) to provide an overview of the current state of research, (2) to classify the diversity of research approaches by identifying clusters of publications that address cultural ecosystem services in similar ways, and (3) to highlight some important challenges for the future of cultural ecosystem services research. We reviewed 107 publications and extracted 20 attributes describing their type and content, including methods, scales, drivers of change, and trade-offs between services. Using a cluster analysis on a subset of attributes we identified five groups of publications: Group 1, conceptual focus, deals with theoretical issues; Group 2, descriptive reviews, consists mostly of desktop studies; Group 3, localized outcomes, deals with case studies coming from different disciplines; Group 4, social and participatory, deals mainly with assessing preferences and perceptions; and Group 5, economic assessments, provides economic valuations. Emerging themes in cultural ecosystem services research relate to improving methods for cultural ecosystem services valuation, studying cultural ecosystem services in the context of ecosystem service bundles, and more clearly articulating policy implications. Based on our findings, we conclude that: (1) cultural ecosystem services are well placed as a tool to bridge gaps between different academic disciplines and research communities, (2) capitalizing on the societal relevance of cultural ecosystem services could help address real-world problems, and (3) cultural ecosystem services have the potential to foster new conceptual links between alternative logics relating to a variety of social and ecological issues.
\end{abstract}

Key Words: aesthetic values; bundling; CES valuation; cluster analysis; cultural heritage; cultural landscapes; drivers of change; intangible benefits; landscape values; nonuse values; policy implications; recreation and ecotourism

\section{INTRODUCTION}

The Millennium Ecosystem Assessment (Sarukhán and Whyte 2005) defined cultural ecosystem services as "the nonmaterial benefits people obtain from ecosystems through spiritual enrichment, cognitive development, reflection, recreation, and aesthetic experiences". Cultural ecosystem services have been included in many other typologies of ecosystem services and referred to variously as cultural services (Constanza 1997), life-fulfilling functions (Daily 1999), information functions (de Groot et al. 2002), amenities and fulfillment (Boyd and Banzhaf 2007), cultural and amenity services (de Groot et al. 2010, Kumar 2010), or sociocultural fulfillment (Wallace 2007).

One broadly agreed upon characteristic of cultural ecosystem services is their intangibility. Intangibility has been advanced both as an explanation for their poor appraisal (Sarukhán and Whyte 2005, Adekola and Mitchell 2011, Daw et al. 2011), but also as an impetus for better consideration of them in the future (Chiesura and de Groot 2003, Chan et al. 2011, Smith et al. 2011). The physical, emotional, and mental benefits produced by cultural ecosystem services are often subtle and intuitive in nature (Kenter et al. 2011) and implicitly expressed through indirect manifestations (Anthony et al. 2009). The value assigned to cultural ecosystem services depends therefore on individual and cultural assessments of their contribution to well-being (Charles and Dukes 2007, Eicken et al. 2009, Scullion et al. 2011). The Millennium Ecosystem Assessment definition of cultural ecosystem services has been criticized because it does not clearly separate, based on their connectedness to the welfare of human beneficiaries, between the above notions of services, benefits, and values (see Boyd and Banzhaf 2007, Wallace 2007, Chan et al. 2012). Cultural ecosystem services are frequently dependent on intermediate ecosystem services (Fisher et al. 2009, Johnston and Russell 2011), and cultural benefits derive from final cultural ecosystem services combined with other forms of capital (Chan et al. 2011, Constanza et al. 2011).

Cultural ecosystem services are usually included under nonconsumptive direct use values (Sarukhán and Whyte 2003) and suffer from poor quantification and integration in management plans (de Groot et al. 2005). With the exception of recreational and aesthetic values (Chan and Ruckelshaus 2010) and cultural heritage and educational values (Kumar 2010), cultural ecosystem services are seldom reflected by economic indicators (e.g., real estate prices) and are rarely marketable (e.g., Carpenter et al. 2009, Martín-López et al. 2009).

\footnotetext{
${ }^{1}$ Institute of Ecology, Faculty of Sustainability, Leuphana University, Lüneburg, ${ }^{2}$ Futures of Ecosystem Services (FuturES) Research Center, Leuphana University, Lüneburg
} 
Cultural ecosystem services are important in a wide range of settings. Industrialized societies often value cultural ecosystem services ahead of other services (Quétier et al. 2010, Tielbörger et al. 2010, Palomo and Montes 2011). Demand for cultural ecosystem services is expected to further grow in industrialized societies (Carpenter et al. 2009, Guo et al. 2010, Ingold and Zimmermann 2011) owing to increasing budget shares for recreation (Vandewalle et al. 2008). By contrast, in traditional communities, cultural ecosystem services are essential for cultural identity and even survival (e.g., Le Maitre et al. 2007, Voora and Barg 2008, Brown and Neil 2011). Although cultural ecosystem services are greatly valued by diverse stakeholders and score highly in assessments of public perceptions, they are sometimes sacrificed by decision makers for economic and ecological reasons (de Groot et al. 2005, Chan et al. 2011, Hendee 2011).

Cultural ecosystem services research engages disciplines including ecology, economics, and the social sciences, and uses a wide range of research approaches. Despite input from multiple disciplinary, methodological, and theoretical perspectives, there is broad agreement that a satisfactory level of understanding of many important facets of cultural ecosystem services has not yet been attained (de Groot et al. 2005, Beaumont et al. 2008, Gasparatos et al. 2011). Moreover, many authors are increasingly sending signals that cultural ecosystem services deserve attention beyond the label of an Millennium Ecosystem Assessment category, but nevertheless fail to address this problem convincingly. We provide a semiquantitative literature review of publications explicitly dealing with cultural ecosystem services. First, we provide an overview of the current state of literature by discussing the temporal trends, the geographical distribution of case studies, the methods, and the background disciplines of cultural ecosystem services research. Second, within the diversity of research perspectives on cultural ecosystem services, we identify clusters of publications that address cultural ecosystem services in similar ways. Third, based on our findings, we highlight some important challenges for the future of cultural ecosystem services research.

\section{METHODS}

We conducted a comprehensive search of ISI Web of Knowledge and of Scopus, using the search terms (1) "cultural ecosystem service*", (2) "cultural services", and (3)" cultural service*" AND "ecosystem service*" in order to identify existing literature dealing specifically with cultural ecosystem services. Moreover, a full-text search for the term "cultural ecosystem service*" was performed in Science Direct. Because a significant proportion of cultural ecosystem services research is not published in peer-reviewed journals, we supplemented the peer-reviewed literature survey by a more subjective search of the 100 most-cited publications in Google Scholar. By reviewing both peer-reviewed and other highly-cited sources, we hoped to provide a more comprehensive review of the current state of cultural ecosystem services research.

Following the searches, we limited the literature set to items published between 2005 (coinciding with the publication of the Millennium Ecosystem Assessment synthesis reports) and January 2012. We excluded articles that mentioned cultural ecosystem services only in the context of listing other ecosystem services categories, articles in languages other than English, publications that could not be located, and conference abstracts. Some articles appeared in several academic databases. We retained 104 publications for in-depth analysis, to which we added three additional relevant publications (Elmqvist et al. 2010, Vandewalle et al. 2008, Vejre et al. 2010) that were cited in key papers. For full transparency, a list of all publications is provided in Table A1.1 (Appendix 1). We acknowledge that these publications do not comprise every single paper that mentioned cultural ecosystem services, but they do allow us to gain a broad overview on the most significant literature and to draw reliable conclusions on recent approaches to cultural ecosystem services research.

For each publication we answered twenty questions that were formulated in association with our research objectives and were built upon preliminary literature reviews and expert judgment (Table A2.1, Appendix 2). Questions sought to gather basic information about the reviewed literature including when, where, by whom, how, and why the research took place. Other questions targeted critiques of the categorization of cultural ecosystem services, namely the inclusion of ecotourism as a cultural ecosystem service (Kumar 2010) and the limited consideration of cultural ecosystem services subcategories (Vihervaara et al. 2010b). To gain a deeper understanding of the research field, we asked to what extent recent themes such as economic versus noneconomic valuation, ecosystem services bundling, mapping, and multidisciplinarity were addressed.

All questions were initially tested and modified on a subset of publications. Response categories were based on the Millennium Ecosystem Assessment and other works (Table A2.1, Appendix 2). For example, because some authors consider both use and nonuse values of cultural ecosystem services-including existence, bequest, and option values (e. g., Gee and Burkhard 2010, Finnoff et al. 2012) and the intrinsic value of ecosystems (e.g., Raymond et al. 2009, Burkhard et al. 2012) —we considered these as a subcategory of cultural ecosystem services. Publications could fall in multiple categories in the case of seven questions (Table A2.1, Appendix 2; for example, Maass et al. (2005) gathered information at all four spatial scales considered). When information relating to some of the questions was not provided or did not apply to the text of the publication, the response was classified as Not Applicable (Table A2.1, Appendix 2). 
We used descriptive statistics to identify how many publications fell into which categories of the 20 extracted attributes. We conducted a cluster analysis on 9 of the 20 questions that best addressed our objective of identifying groups of publications that approach cultural ecosystem services in similar ways (Table A2.1, Appendix 2). Specifically, we ran an agglomerative hierarchical cluster analysis using Euclidian distances and Ward's method. Taking into account all variables, this method starts by clustering single elements (i.e., papers) into aggregates of two elements. Next, it clusters the previous aggregates and does so, following a bottom-up logic, until one cluster remains (Everitt et al. 2001). The premise is to minimize within-group variance and maximize dissimilarities between groups. We chose Ward's clustering because it is widely used and understood, and readily interpretable. The quantitative assessment and its interpretation were complemented by a qualitative reading of the literature.

\section{RESULTS}

\section{Overview and general patterns}

The publications included 84 peer-reviewed articles, two Millennium Ecosystem Assessment chapters, four full papers presented at conferences, three book chapters, five $\mathrm{PhD}$ and Master theses, three working publications and six reports (Table A1.1, Appendix 1). Cultural ecosystem services is a growing research field with an increasing number of publications (Fig. 1). Thirty-nine publications acknowledged the existence of cultural ecosystem services in less than $5 \%$ of the text, and 42 publications discussed cultural ecosystem services alongside other Millennium Ecosystem Assessment categories in 5 to $25 \%$ of the text. These 81 papers generally mentioned cultural ecosystem services within an enumeration of the types of ecosystem services and provided little new insight specifically on cultural ecosystem services. Eleven publications devoted between a quarter and a half of the text to cultural ecosystem services, and ten publications focused on cultural ecosystem services in more than $50 \%$ and up to $75 \%$ of the text. Only five publications were entirely dedicated to cultural ecosystem services (de Groot et. al 2005, Gee and Burkhard 2010, Chan et al. 2011, Chan et al. 2012, Norton et al. 2012). Publications dedicating more than half of their content to cultural ecosystem services were typically published after 2009. The publications came from eight academic disciplines (Table 1); 72 publications contained case studies, 32 included strong conceptual elements (e.g., Burkhard et al. 2012), and 21 were reviews.

We examined service providers, geographical distribution, cultural ecosystem services subcategories, methods, and drivers of change. Most publications named, as suppliers of cultural ecosystem services, specific types of ecosystems $(n=54)$ such as coastal ecosystems or urban green areas, or specific geographical areas $(n=25)$. Fewer publications focused on specific species $(n=8)$ or specific stocks of
Table 1. Number of publications according to the discipline of the first author. (For three of the authors, information regarding their disciplines was not available.)

\begin{tabular}{lc}
\hline \hline Discipline & $\begin{array}{c}\text { Publications } \\
\text { (no.) }\end{array}$ \\
\hline $\begin{array}{l}\text { Biodiversity conservation and } \\
\text { ecology }\end{array}$ & 45 \\
$\begin{array}{l}\text { Environmental management and } \\
\text { policy making }\end{array}$ & 33 \\
$\begin{array}{l}\text { Others } \\
\text { geography, social sciences, } \\
\text { engineering, chemistry) }\end{array}$ & 10 \\
$\begin{array}{l}\text { Agriculture and forestry } \\
\text { Economics }\end{array}$ & \\
\hline
\end{tabular}

natural capital and associated human activities $(n=8)$. The majority of the case studies were in the USA $(n=12)$; the others were in the UK $(n=10)$, Germany $(n=8)$, Spain $(n=8)$, Australia $(n=4)$, and Finland ( $n=4)$ (Fig. 2). Sixteen case studies were at the landscape scale $\left(1000\right.$ to $9999 \mathrm{~km}^{2}$ ) while local (0 to $\left.999 \mathrm{~km}^{2}\right)$, regional $\left(10,000\right.$ to $\left.99,999 \mathrm{~km}^{2}\right)$, and national or global scales were represented each by approximately $20 \%$ of case studies. The first three cultural ecosystem services subcategories were investigated more often than all the other eight subcategories put together (Fig. 3). Qualitative, quantitative, and mixed methodologies were used across all scales and regardless of disciplines, with a general preference for mixed $(n=42)$ and qualitative methods $(n=38)$ rather than quantitative ones $(n=17)$. Sixty-four publications discussed one or more specific drivers promoting change of cultural ecosystem services, either directly (e.g., decision making, management), or indirectly (land use, resource depletion) (Fig. 4).

Fig. 1. Number of publications per year.

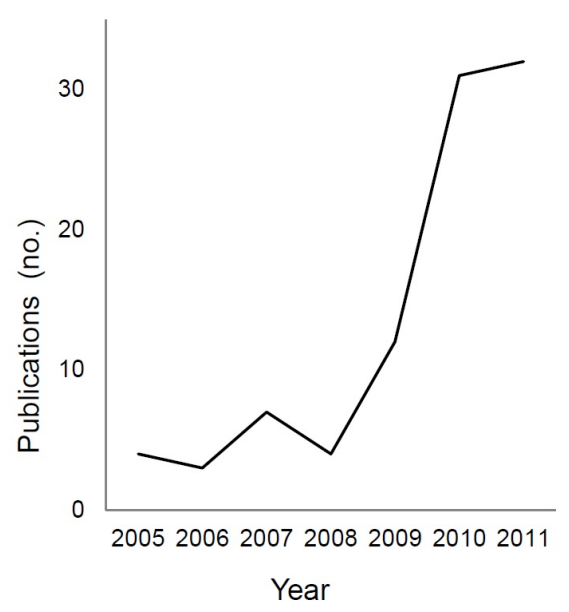




\section{Elicitation and valuation}

Thirty-five publications undertook or conceptualized economic valuation of cultural ecosystem services, often in relation to recreation and ecotourism. By contrast, twentyseven specifically argued against monetary valuation of cultural ecosystem services. Where economic valuation was undertaken, stated preference, revealed preference, and market price methods were by far the most employed (Fig. 5).

Fig. 2. Regional distribution of case studies in the review. Publications could have no entries or multiple entries if, respectively, they contained no or multiple case studies. Case studies located in Europe included three pan-European studies (Ding 2009, Harrison et al. 2010, Vilà et al. 2010).

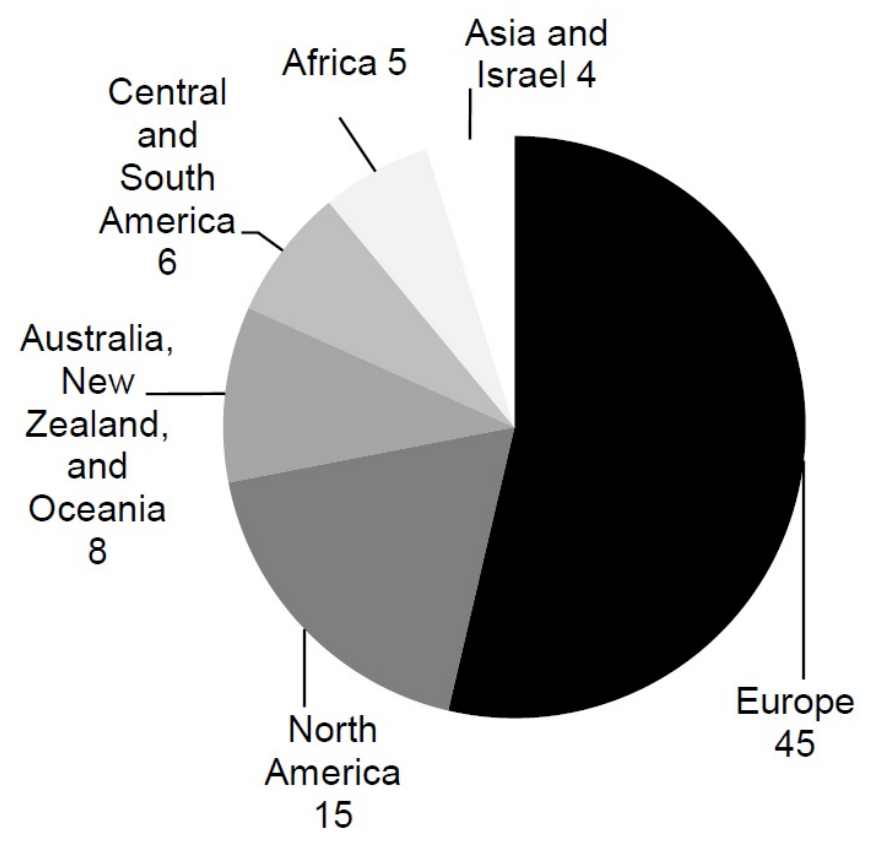

Forty-seven publications involved or envisaged involving stakeholders to identify, assess, or otherwise value cultural ecosystem services. More than half the reviewed items $(n=55)$ acknowledged the contribution of cultural ecosystem services to well-being or health, particularly through mental benefits (e.g., Niemelä et al. 2010, Tzoulas and James 2010) but these were rarely quantified. Twenty publications presented maps or ways to map cultural ecosystem services (e.g., González et al. 2010). Forty-two publications discussed trade-offs between cultural ecosystem services and other services (e.g., Rodríguez et al. 2006), but only thirteen publications explicitly considered ecosystem services bundles (e.g., RaudseppHearne et al. 2010a).

\section{Cluster analysis}

Five clusters were chosen as a meaningful compromise between generality and specificity of results (Fig. 6). The strength of the resulting clustering had an agglomerative coefficient of 0.9 ( 1 being the maximum). We applied a topdown logic when interpreting the cluster analysis. The top node of the dendrogram (Fig. 6) generated two broad categories based predominantly on the presence or absence of a specified scale. The first group, called conceptual focus, contained predominantly theoretical publications $(n=25)$. Such publications specified recommendations or advanced theoretical frameworks for conceptualizing and evaluating ecosystem services (e.g., Butler and Oluoch-Kosura 2006, Carpenter et al. 2009, Daily et al. 2009, Seppelt et al. 2012). These publications typically addressed challenging concepts such as the questions of bundling in ecosystem services or the suitability of noneconomic valuation techniques (e.g., Rodríguez et al. 2006, Viglizzo et al. 2012). This group tended to pioneer new research directions, such as agricultural production as a source of cultural and utilitarian cobenefits (Swinton et al. 2007, Power 2010).

The cluster of descriptive reviews $(n=25)$ contained mostly papers that did not use quantitative methods and which allocated up to one quarter of text length to cultural ecosystem services. These publications rarely discussed trade-offs and focused mostly on direct drivers of change. They typically aimed to document, backed mostly by references, the range and relative importance of ecosystem services delivered in changing conditions by suppliers, and typically argued that cultural ecosystem services needed more attention, thus appealing for more research (e.g., Ljung et al. 2009, Kunz et al. 2011, Lundy and Wade 2011).

The largest cluster of publications, localized outcomes $(n=32)$, dealt with case studies typically seeking to advance qualitative arguments for the conservation of a particular ecosystem or area (e.g., Kovarik et al. 2011). They ranged from publications reporting the values and benefits associated with particular locations (e.g., open spaces) (Wang et al. 2012) or ecosystems (e.g., wetlands) (Moore and Hunt 2012) to those dealing with the effects of specific threats (e.g., Schröter 2005, Burgess et al. 2010, Kløve et al. 2011) or policies and management approaches on place-based cultural ecosystem services (e.g., Nainggolan et al. 2011). Many of these publications discussed conflicting situations (e.g., Vihervaara et al. 2010a) and tradeoffs between alternative development strategies (e.g., LópezHoffman et al. 2010). They mostly used information from other research communities (sensu Q20, Table A2.1) (e.g., Norton et al. 2012).

Publications that placed people first, by quantifying preferences and perceptions, were aggregated in the fourth cluster, termed social and participatory $(n=13)$. While the previous clusters were mainly concerned with conservation and development objectives, publications in this group emphasized the social aspects of case studies (e.g., Kenter et al. 2011, Palomo and Montes 2011), or considered the 
Fig. 3. Number of publications investigating different subcategories of cultural ecosystem services. Publications could have no entries or multiple entries if, respectively, no or multiple subcategories were addressed.

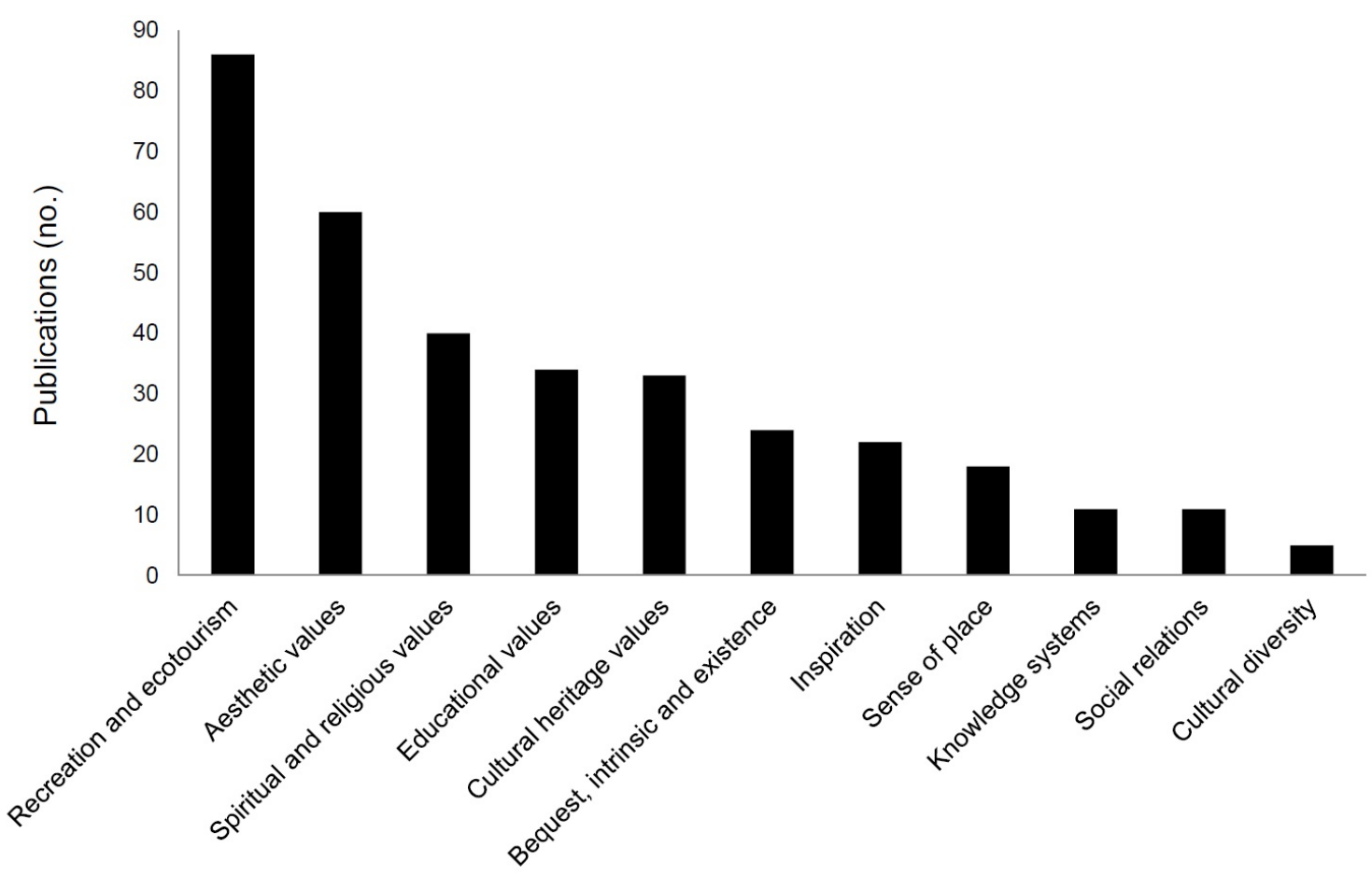

Subcategories

Fig. 4. Number of publications dealing with different drivers of cultural ecosystem service change: (a) direct drivers, and (b) indirect drivers. Some publications discussed no drivers or multiple drivers.

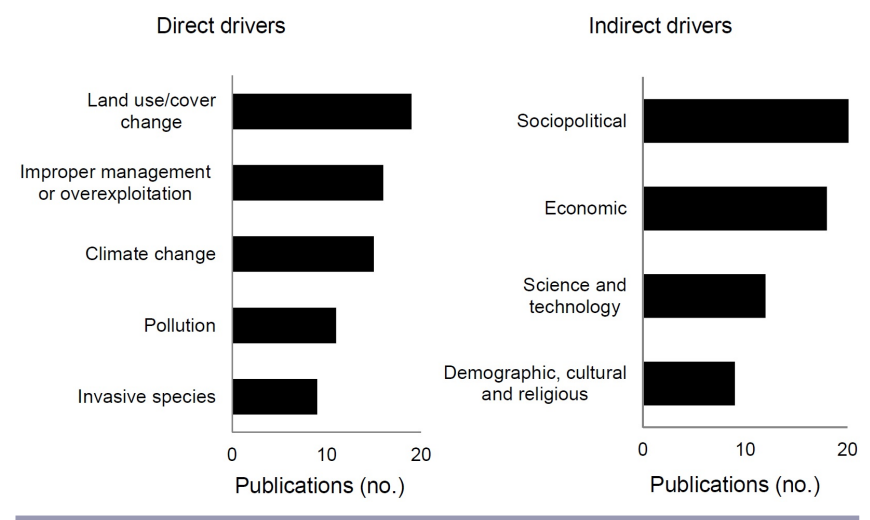

Fig. 5. Number of publications applying or discussing different economic techniques used to value cultural ecosystem services. Some publications approached none or multiple of these techniques.

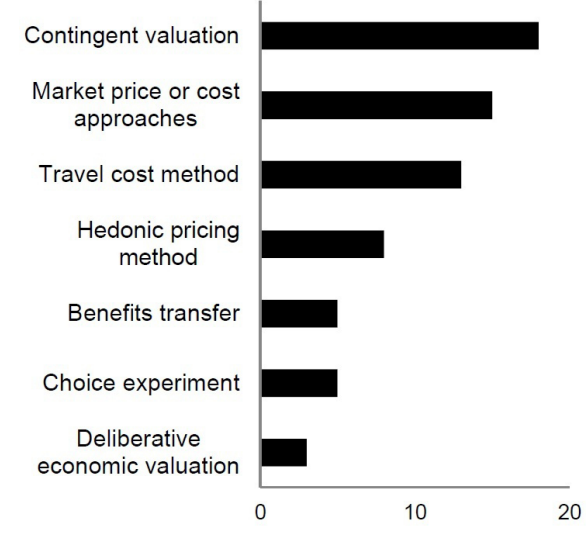

Publications (no.) 
Fig. 6. Dendrogram showing the five groups of publications identified by the cluster analysis.

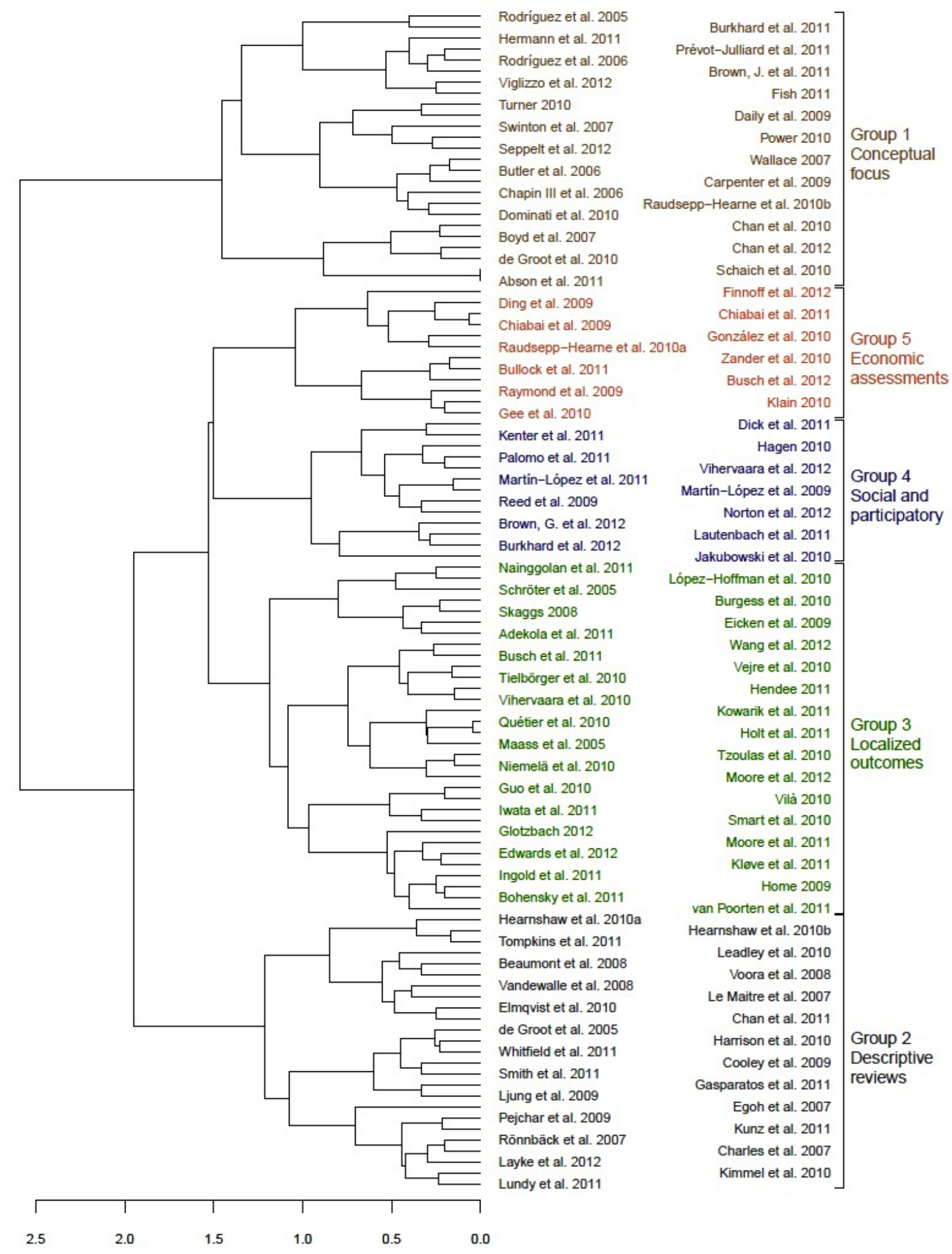


contribution of stakeholders to knowledge, emphasizing participatory techniques (e.g., Brown et al. 2012).

The fifth cluster, economic assessments $(n=12)$, was centered around the present (e.g., Chiabai et al. 2011) or future (e.g., Ding et al. 2009) economic value of ecosystem services. Using quantitative methods (econometric models, spatial valuation), these case studies aimed to communicate factual, often monetary, accounts of cultural ecosystem services to be incorporated by policy makers (e.g., Zander et al. 2010, González et al. 2010).

\section{DISCUSSION}

\section{Heterogeneous perspectives of cultural ecosystem services research}

Cultural ecosystem services have attracted attention in a wide variety of publications, originating from multiple academic disciplines, and employing heterogeneous approaches. The heterogeneity in approaches to cultural ecosystem services research may result from three interacting circumstances. First, a diversity of approaches and apparent lack of cohesiveness rightfully corresponds to the eclectic nature of cultural ecosystem services (as described in the introduction).

Second, within all clusters, cultural ecosystem services tended not to be the priority focus of research projects; rather, cultural ecosystem services were considered as part of a broader analysis. Therefore, cultural ecosystem services are often assessed using methods initially designed to address broader research questions, with the concept of cultural ecosystem services loosely related to the actual research outputs. Cultural ecosystem services being somewhat peripheral in most papers is also indicated by the typically low proportion of text dedicated to cultural ecosystem services (Q2).

Third, the multitude of perspectives on cultural ecosystem services reflects the development of a relatively new field of research that lacks a well-established, reproducible research framework. Improved definitions and more widely acknowledged methodologies and research agendas are required. Cultural ecosystem services is a vibrant research arena where incipient directions are starting to crystallize and move away from the initial labels of a "generic" (Vihervaara $2010 b$ ) or even "residual" ecosystem services categoryencompassing everything that does not fit in the more utilitarian classes of ecosystem services (Chan et al. 2012, Daniel et al. 2012).

\section{Drivers of change for cultural ecosystem services}

Regarding the drivers of change in cultural ecosystem services, published accounts are again diverse. We found that the socioeconomic drivers impacting on cultural ecosystem services provision (Q11) differ across countries (Q6), with issues such as poverty and corruption (López-Hoffman et al.
2010, Glotzbach 2012) being predominant in relatively poor countries, whereas cultural ecosystem services in industrialized societies are more commonly affected by drivers of change related to science or technology (e.g., through the development of renewable energies, agricultural intensification, dam building) (Bullock and Collier 2011, Busch et al. 2011, Tompkins et al. 2011). In a context where more than half of all publications come from Europe and North America (Fig. 2), such divergent trends between developing and developed countries must not be forgotten, especially given the tendency of Western cultures to underestimate the importance of cultural ecosystem services for rural livelihoods and identities (Bohensky et al. 2004).

\section{Valuing cultural ecosystem services}

The majority of cultural ecosystem services are placed outside the methods of neoclassical economics (e.g., Chan et al. 2012) but some researchers consider their value measurable since they are expressed in human action (e.g., Boyd and Banzhaf 2007, Zhang et al. 2010). The Economics of Ecosystems and Biodiversity initiative (2010a), for example, clearly delineated a subset of cultural ecosystem services amenable to traditional valuation: recreation, ecotourism, cultural heritage, and educational values. Unsurprisingly, the most frequently studied cultural ecosystem services (Fig. 3) are the most easily quantifiable (e.g., Chan and Ruckelshaus 2010), further deepening the gap between counting that which matters to people and that which is easy to measure. Although recreation and ecotourism are routinely considered as cultural ecosystem services (e.g., de Groot et al. 2010), some authors have argued that they should instead be classified as provisioning services (Abson and Termansen 2011), especially for communities strictly dependent on these services (Rounsevell et al. 2010, Daw et al. 2011). An overemphasis on recreation and ecotourism, although pointing to a general helplessness towards measuring other cultural ecosystem services, may lead researchers and policymakers to assume that these represent cultural ecosystem services as a whole, thereby contributing to an unconscious marginalization of other important cultural ecosystem services (Fig. 3, see also Liu et al. 2010, Seppelt et al. 2011). For example, our review shows that cultural ecosystem services often produce spiritual benefits, but these are not quantified.

\section{Alternatives for valuing cultural ecosystem services}

The adequacy of established economic techniques (Fig. 5) to capture cultural norms and express plurality of values (Sukhdev et al. 2010) remains contested (e.g., Kumar and Kumar 2008, Klain 2010, Tielbörger et al. 2010). Revealed preference based monetary valuation is dependent on consumers' sovereignty and not on ecological conditions. For example, the ease of accessibility is a crucial factor typically included in the monetization of recreational services (de Groot et al. 2010, Lautenbach et al. 2011). Moreover, cultural ecosystem services cannot be split into discrete units for 
marginal valuation (Abson and Termansen 2011) or into spatial units of actual cultural ecosystem services "consumption" (Burkhard et al. 2012). To overcome these problems, some authors recommend describing cultural ecosystem services via ordinal classes (Seppelt et al. 2012), or descriptors, such as "charismatic landscape" or "appropriate diversity" (Norton et al. 2012). Proxies such as percentage of land under protected status, donations to conservation agencies (Rössler 2006, Raudsepp-Hearne et al. 2010b), the presence of labeled products (Kumar 2010), tracing visible manifestations of cultural ecosystem services on the physical landscape (Bieling et al. 2012), or the number of studies about an ecosystem (e.g., Tompkins et al. 2011) provide useful alternatives for revealing the values ascribed to cultural ecosystem services.

Given inherent problems with monetary valuation, many authors increasingly focus on noneconomic deliberative techniques (e.g., Daily et al. 2009, Turner 2010, Abson and Termansen 2011) such as Delphi surveys (Edwards et al. 2012) or the Q method (Kerr and Swaffield 2007). Some authors specifically argue for using methods that reflect the relationship between a specific cultural service and its user, including personal experience, imagination, expectation, and preference (e.g., Martín-López et al. 2009, Gee and Burkhard 2010), thereby achieving an explicit psycho-cultural perspective (Kumar and Kumar 2008). An increasingly popular alternative to valuation is the spatial representation of ecosystem services (Kumar 2010), which is frequently associated with participatory mapping (Raymond et al. 2009, Sherrouse et al. 2011, Plieninger et al. 2013) or photo-based methods (Williams and Cary 2001, Sherren et al. 2010).

\section{Bundling cultural ecosystem services}

Bundling of ecosystem services (Q19) and its implications for navigating trade-offs and synergies between services constitutes another major challenge for the valuation of ecosystem services (Bennett et al. 2009). However, our review has shown that the concept of bundling has been embraced by few cultural ecosystem services researchers. Many authors still think primarily in a hierarchy of trade-offs between different kinds of services (e.g., cultural versus provisioning), rather than recognizing their potentially interlinked nature. Authors who do consider bundles typically recognize the existence of combinations of ecosystem services that flow from particular landscapes (Carpenter et al. 2009) or ecosystems (Dick et al. 2011, Whitfield et al. 2011), interdependencies between different types of ecosystem services (Hermann et al. 2011), and joint production of services (Busch et al. 2011, Finnoff et al. 2012). Particularly in the context of agro-ecosystems, the discussion of cultural ecosystem services often is centered on their multifunctionality and on studying several ecosystem services in parallel (Swinton et al. 2007, Gordon et al. 2010, Lautenbach et al. 2011).

\section{Inclusion of cultural ecosystem services in decision making}

There is a debate about whether cultural ecosystem services are properly considered in real decision contexts (e.g., Gee and Burkhard 2010, Schaich et al. 2010). While many authors consider cultural ecosystem services as under-studied and under-regarded, some argue that literature on economic valuation and planning recognizes cultural ecosystem services more strongly than regulating and supporting services (Egoh et al. 2007, Bennett et al. 2009, Wittmer et al. 2010). We believe that these two positions may co-exist, in part due to the tendency of cultural ecosystem services research to focus on specific subcategories of cultural ecosystem services (Fig. 3 ) and not on the whole range of cultural ecosystem services. As with the secondary focus on cultural ecosystem services in terms of research agendas, cultural ecosystem services usually serve as a complementary-rather than a leading-incentive for orientating decisions. Nearly all studies recommended, to some extent, the integration of ecosystem services in management plans (Dominati et al. 2010, Kimmel and Mander 2010). However, few papers explicitly tackled the challenge of accounting for socio-cultural values in ecosystem services assessments (Raudsepp-Hearne et al. 2010b, Tzoulas and James 2010) or as stimuli for the conservation of biodiversity (e.g., Khan et al. 2008, Haslett et al. 2010, Everard and Kataria 2011). Even fewer acknowledged the need to adapt institutional arrangements to a nonutilitarian perspective (e. g., Daily et al. 2009, Holt et al. 2011).

\section{Cultural ecosystem services, multidisciplinarity, and other schools of thought}

Our results underlined that to gain a holistic understanding of ecosystem services, economics, other social sciences, and the humanities, are just as important as ecology (Table 1). Being related to human perceptions, attitudes and beliefs, cultural ecosystem services highlight powerful linkages with the social sciences (e.g., Wallace 2007, Daily et al. 2009, Chan et al. 2012). Insights from psychology, anthropology and behavioral studies, similar to those obtained by the social and participatory cluster, move the focus from individual needs to those fulfilled at a collective level (e.g., Chiesura and de Groot 2003, Turner 2010, Daniel et al. 2012). They highlight the concrete contribution of cultural ecosystem services to human well-being, public health (e.g., Dallimer et al. 2012) and psychological experiences (Vejre et al. 2010). Despite this, our review shows a low level of involvement of social scientists in cultural ecosystem services research. As Fish (2011) argued, cultural scholars may be more inclined to find the concept of cultural ecosystem services in conflict with the nonutilitarian and nonlinear meaning of "culture" from the social literature and therefore may be reticent to adopting an ecosystem services framework.

Collaboration and exchange with closely related fields of research will be equally necessary. In our research, we 
uncovered a range of publications that partially overlapped with the concept of cultural ecosystem services. However, many of these studies were not identified in our literature search because they did not use the terminology associated with ecosystem services. Examples include studies on people's sense of place (e.g., Soini et al. 2012), work on landscape preferences (e.g., Conrad et al. 2011), place attachment (e.g., Brown and Raymond 2007), cultural heritage (Tolentino 2007), and traditional knowledge (Yeo-Chang 2009). Our review thus reflects only a subset of literature about nature's intangible benefits to people, because parallel work is taking place in other research communities that do not use the term ecosystem services. Deeper engagement with scientists working with alternative phrases such as landscape values (e.g., Brown 2005, Haaland et al. 2011), community values (Raymond et al. 2009), social values (Fagerholm and Käyhkö 2009), landscape services (Enengel et al. 2009, Termorshuizen and Opdam 2009), visual qualities (Arriaza et al. 2004), experiential values (Barthel et al. 2005), and amenity values (Kerr and Swaffield 2007) could further strengthen the methodological and philosophical foundations of cultural ecosystem services research.

Literature on the relationships of people with cultural landscapes appears particularly important (Giannecchini et al. 2007) as the awareness of services provided by a certain region or land-use is increasing (Lamarque et al. 2011). Cultural landscapes are a good point of departure (Vejre et al. 2010) for cultural ecosystem services research not least because they incorporate many of the concepts that fall outside the Millennium Ecosystem Assessment framework. In our sample, 41 out of 107 publications cited at least one reference from typical "landscape journals", such as Landscape and Urban Planning, Landscape Ecology, or Landscape Research. The mutual recognition between the ecosystem services approach and (cultural) landscape research has been acknowledged for some time (de Groot et al. 2005), and recent work noted a similarity of scopes and potential for cross fertilization (Schaich et al. 2010, Hermann et al. 2011, Gee and Burkhard 2010).

\section{FUTURE CHALLENGES AND CONCLUSION}

Our review showed that there are various valid points of departure within the cultural ecosystem services research field. The emergence of five discrete research clusters reveals plausible alternatives, i.e., distinct ways to conceptualize and measure cultural ecosystem services that carry their own achievements and flaws and provide researchers with rich opportunities to learn and to adapt. A particular challenge is to develop coherent approaches to cultural ecosystem services research while remaining connected to the wider ecosystem services research community. With a view to advancing cooperation on cultural ecosystem services within the scientific community and with practitioners, we propose the following: (1) greater synthesis of the existing approaches to cultural ecosystem services found in different research communities, (2) capitalizing on the societal relevance of cultural ecosystem services to address real-world problems, and (3) mobilizing cultural ecosystem services as a conceptual bridging element between various social and ecological constructs. Although universal, each of these challenges tends to be better met by one of the five clusters.

First, cultural ecosystem services are well placed to bridge gaps between different disciplines, research communities, and intellectual heritages. Cultural ecosystem services is a relatively young research field that does not wear the burden of entrenched academic traditions or paradigms. The diversity of research on cultural ecosystem services indicates scientific dynamism but at the same time, the lack of a solid common terminology and understanding. The five clusters carry the danger of drifting into very specialized and potentially sealedoff ways of thinking. Greater synthesis of these different research approaches may help reduce the production of disconnected understandings of cultural ecosystem services. The divergent perspectives illustrated by the five clusters (or by parallel research communities for that matter) should not be in competition but, rather, should be complementary. For example, cultural landscape research shares many objectives with research on cultural ecosystem services which sometimes uses similar elicitation methods as traditional social sciences. Interdisciplinary case studies that have cultural ecosystem services as a secondary concern (localized outcomes) are benefiting from comprehensive studies that appeal for research (descriptive reviews) or theoretical progress (conceptual focus). Similarly, cultural ecosystem services are caught in between the economic focus of economic assessments and the socio-psychological perspective of being social and participatory, while, in order to have a holistic understanding of human-environment relationships, both perspectives are needed. We stress that cultural ecosystem services call for diverse elicitation and valuation methods across multiple scales and types of societies, which is an approach that offers opportunities for exchange and innovation.

Second, capitalizing on the societal relevance of cultural ecosystem services could help address real-world problems. Practitioners and scientists alike recognize at least some cultural ecosystem services as contributors to human wellbeing, but also envisage integrating them in conservation plans. Thanks to their interdependence with other ecosystem services (Kumar 2010) and their intimately rooted familiarity to the stakeholders of a given ecosystem, the "tacit" values of cultural ecosystem services (Anthony et al. 2009) are an accessible and effective vehicle for the multistakeholder, holistic management of ecosystems. Authors have suggested that including immaterial benefits in the management of natural resources can improve the social acceptance and legitimacy of management decisions (e.g., Leadley et al. 
2010). For example, the social and participatory research cluster seems especially well positioned to use its secondary focus on cultural ecosystem services to illustrate that the aesthetic value of a landscape is indispensable in the eyes of the broader public (Tielbörger et al. 2010). On the contrary, the factual accounts provided by the economic assessments cluster and the localized outcomes cluster are less successful in making cultural values key to environmental awareness, collective action, and ecosystem stewardship (Hendee 2011, Chan et al. 2012). Our research suggests that cultural ecosystem services can be used as an effective foot in the door for engaging actors who have different values and goals.

Third, cultural ecosystem services have the potential to foster new conceptual links between logics relating to a variety of social and ecological issues. The conceptual focus cluster is best placed to have a positive effect on the development of cultural ecosystem services research at a theoretical level. The conceptual openness shared by these papers may reveal new paths to reconnect humanity and nature in the twenty-first century (Fischer et al. 2012). We believe that cultural ecosystem services can serve as stepping stones in today's sea of ideas by, for example, creating congruencies between social-ecological systems theory and the ecosystem services framework. Cultural ecosystem services have the potential to trigger the evolution of the ecosystem services framework in a direction that more deeply engages people and accounts for social values (Kumar and Kumar 2008). Thoroughly accounting for cultural ecosystem services would help to balance primarily economic considerations (Hearnshaw and Cullen 2010) and facilitate a more inclusive social-ecological approach by exploring the interactions between social and ecological processes. In our view, mobilizing cultural ecosystem services as binding elements between social and ecological conceptual constructs meets the core idea of the sustainability ideal.

Our review illustrates that literature on cultural ecosystem services, while making conceptual advances, deals with many topics and addresses cultural ecosystem services in a diversity of ways. Within this diversity of concepts, measurements, and valuations, five relatively distinctive foci of cultural ecosystem services literature were found. The notion of cultural ecosystem services has generated a myriad of ideas, and, most likely, we will witness in the coming years the rapid evolution of this research field. Based on our findings we anticipate a future increase in papers that are social and participatory or have conceptual focus. Embracing different cultural ecosystem services research approaches, including their vagueness and intangibility, may contribute to the resolution of real-world problems in the management of human-nature interactions.

Responses to this article can be read online at: http://www.ecologyandsociety.org/issues/responses. $\mathrm{php} / 5790$

\section{Acknowledgments:}

We thank the two anonymous reviewers for their helpful comments, which greatly improved the manuscript. We would like to thank Kate Sherren for insightful discussions. The research was funded through a Sofja Kovalevskaja Award by the Alexander von Humboldt Foundation to Joern Fischer, financed by the German Ministry for Research and Education.

\section{LITERATURE CITED}

Abson, D. J., and M. Termansen. 2011. Valuing ecosystem services in terms of ecological risks and returns. Conservation Biology 25:250-258.

Adekola, O., and G. Mitchell. 2011. The Niger Delta wetlands: threats to ecosystem services, their importance to dependent communities and possible management measures. International Journal of Biodiversity Science, Ecosystem Services \& Management 7:50-68. http://dx.doi.org/10.1080/21513732.2$\underline{011.603138}$

Anthony, A., J. Atwood, P. August, C. Byron, S. Cobb, C. Foster, C. Fry, A. Gold, K. Hagos, L. Heffner, D. Q. Kellogg, K. Lellis-Dibble, J. J. Opaluch, C. Oviatt, A. Pfeiffer-Herbert, N. Rohr, L. Smith, T. Smythe, J. Swift, and N. Vinhateiro. 2009. Coastal lagoons and climate change: ecological and social ramifications in U.S. Atlantic and Gulf coast ecosystems. Ecology and Society 14(1): 8. [online] URL: http://www.ecologyandsociety.org/vol14/iss1/art8/

Arriaza, M., J. Canasortega, J. Canasmadueno, and P. Ruizaviles. 2004. Assessing the visual quality of rural landscapes. Landscape and Urban Planning 69:115-125. http://dx.doi.org/10.1016/j.landurbplan.2003.10.029

Barthel, S., J. Colding, T. Elmqvist, and C. Folke. 2005. History and local management of a biodiversity-rich, urban cultural landscape. Ecology and Society 10(2): 10. [online] URL: http://www.ecologyandsociety.org/vol10/iss2/art10/

Beaumont, N. J., M. C. Austen, S. C. Mangi, and M. Townsend. 2008. Economic valuation for the conservation of marine biodiversity. Marine Pollution Bulletin 56:386-396. http://dx.doi.org/10.1016/j.marpolbul.2007.11.013

Bennett, E. M., G. D. Peterson, and L. J. Gordon. 2009. Understanding relationships among multiple ecosystem services. Ecology Letters 12:1394-1404. http://dx.doi. org/10.1111/j.1461-0248.2009.01387.x

Bieling, C., and T. Plieninger. 2012. Recording manifestations of cultural ecosystem services in the landscape. Landscape Research 1-19. http://dx.doi.org/10.1080/01426397.2012.691469

Bohensky, E., B. Reyers, A. S. van Jaarsveld, and C. Fabricius, editors. 2004. Ecosystem services in the Gariep Basin: a component of the Southern African Millennium Ecosystem Assessment (SAfMA). African Sun Media, South Africa. 
Boyd, J., and S. Banzhaf. 2007. What are ecosystem services? The need for standardized environmental accounting units. Ecological Economics 63:616-626. http://dx.doi.org/10.1016/ j.ecolecon.2007.01.002

Brown, G. 2005. Mapping spatial attributes in survey research for natural resource management: methods and applications. Society \& Natural Resources 18:17-39. http://dx.doi. org/10.1080/08941920590881853

Brown, G., J. M. Montag, and K. Lyon. 2012. Public participation GIS: a method for identifying ecosystem services. Society \& Natural Resources 25(7):633-651. http:// dx.doi.org/10.1080/08941920.2011.621511

Brown, G., and C. Raymond. 2007. The relationship between place attachment and landscape values: toward mapping place attachment. Applied Geography 27:89-111. http://dx.doi. org/10.1016/j.apgeog.2006.11.002

Brown, J., and M. Neil. 2011. A site-based approach to delivering rangeland ecosystem services. The Rangeland Journal 33:99-108. http://dx.doi.org/10.1071/RJ11006

Bullock, C. H., and M. Collier. 2011. When the public good conflicts with an apparent preference for unsustainable behaviour. Ecological Economics 70:971-977. http://dx.doi. org/10.1016/j.ecolecon.2010.12.013

Burgess, P. J., A. J. Moffat, and R. B. Matthews. 2010. Assessing climate change causes, risks and opportunities in forestry. Outlook on Agriculture 39:263-268. http://dx.doi. org/10.5367/oa.2010.0012

Burkhard, B., F. Kroll, S. Nedkov, and F. Müller. 2012. Mapping ecosystem service supply, demand and budgets. Ecological Indicators 21:17-29. http://dx.doi.org/10.1016/j. ecolind.2011.06.019

Busch, M., K. Gee, B. Burkhard, M. Lange, and N. Stelljes. 2011. Conceptualizing the link between marine ecosystem services and human well-being: the case of offshore wind farming. International Journal of Biodiversity Science, Ecosystem Services \& Management 7:190-203. http://dx.doi. org/10.1080/21513732.2011.618465

Butler, C. D., and W. Oluoch-Kosura. 2006. Linking future ecosystem services and future human well-being. Ecology and Society 11(1): 30. [online] URL: http://www.ecologyandsociety. org/vol11/iss1/art30/

Carpenter, S. R., H. A. Mooney, J. Agard, D. Capistrano, R. S. DeFries, S. Díaz, T. Dietz, A. K. Duraiappah, A. OtengYeboah, H. Miguel, C. Perrings, R. J. Scholes, A. Whyte, and W. V. Reid. 2009. Science for managing ecosystem services: beyond the Millennium Ecosystem Assessment. Proceedings of the National Academy of Sciences of the United States of America 106:1305-1312. http://dx.doi.org/10.1073/pnas.0808772106

Chan, K. M. A., J. Goldstein, T. Satterfield, N. Hannahs, K. Kikiloi, R. Naidoo, N. Vadeboncoeur, and U. Woodside. 2011. Cultural services and non-use values. Pages 206-228 in P. Kareiva, H. Tallis, T. H. Ricketts, G. C. Daily, and S. Polasky, editors. Natural capital: theory and practice of mapping ecosystem services. Oxford University Press, Oxford, UK.

Chan, K. M. A., and M. Ruckelshaus. 2010. Characterizing changes in marine ecosystem services. F1000 Biology Reports 2:54. http://dx.doi.org/10.3410/B2-54

Chan, K. M. A., T. Satterfield, and J. Goldstein. 2012. Rethinking ecosystem services to better address and navigate cultural values. Ecological Economics 74:8-18. http://dx.doi. org/10.1016/j.ecolecon.2011.11.011

Charles, H., and J. S. Dukes. 2007. Impacts of invasive species on ecosystem services. Pages 217-237 in W. Nentwig, editor. Biological invasions. Springer, Berlin, Germany. http://dx. doi.org/10.1007/978-3-540-36920-2 13

Chiabai, A., C. M. Travisi, A. Markandya, H. Ding, and P. A. L. D. Nunes. 2011. Economic assessment of forest ecosystem services losses: cost of policy inaction. Environmental and Resource Economics 50:405-445. http://dx.doi.org/10.1007/ $\underline{\text { s10640-011-9478-6 }}$

Chiesura, A., and R. de Groot. 2003. Critical natural capital: a socio-cultural perspective. Ecological Economics 44:219-231. http://dx.doi.org/10.1016/S0921-8009(02)00275-6

Conrad, E., M. Christie, and I. Fazey. 2011. Understanding public perceptions of landscape: a case study from Gozo, Malta. Applied Geography 31:159-170. http://dx.doi. org/10.1016/j.apgeog.2010.03.009

Constanza, R. 1997. The value of the world's ecosystem services and natural capital. Nature 387:253-260. http://dx. doi.org/10.1038/387253a0

Constanza, R., I. Kubiszewski, D. Ervin, R. Bluffstone, J. Boyd, D. Brown, H. Chang, V. Dujon, E. Granek, S. Polasky, V. Shandas, and A. Yeakley. 2011. Valuing ecological systems and services. F1000 Biology Reports 3:14.

Daily, G. C. 1999. Developing a scientific basis for managing earth's life support systems. Conservation Ecology 3(2):14.

Daily, G. C., S. Polasky, J. Goldstein, P. M. Kareiva, H. A. Mooney, L. Pejchar, T. H. Ricketts, J. Salzman, and R. Shallenberger. 2009. Ecosystem services in decision making: time to deliver. Frontiers in Ecology and the Environment 7:21-28. http://dx.doi.org/10.1890/080025 
Dallimer, M., K. N. Irvine, A. M. J. Skinner, Z. G. Davies, J. R. Rouquette, L. L. Maltby, P. H. Warren, P. R. Armsworth, and K. J. Gaston. 2012. Biodiversity and the feel-good factor: understanding associations between self-reported human well-being and species richness. BioScience 62:47-55. http:// dx.doi.org/10.1525/bio.2012.62.1.9

Daniel, T. C., A. Muhar, A. Arnberger, O. Aznar, J. W. Boyd, K. M. A. Chan, R. Costanza, T. Elmqvist, C. G. Flint, P. H. Gobster, A. Grêt-Regamey, R. Lave, S. Muhar, M. Penker, R. G. Ribe, T. Schauppenlehner, T. Sikor, I. Soloviy, M. Spierenburg, K. Taczanowska, J. Tam, and A. von der Dunk. 2012. Contributions of cultural services to the ecosystem services agenda. Proceedings of the National Academy of Sciences of the United States of America 109(23):8812-8819. http://dx.doi.org/10.1073/pnas.1114773109

Daw, T., K. Brown, S. Rosendo, and R. Pomeroy. 2011. Applying the ecosystem services concept to poverty alleviation: the need to disaggregate human well-being. Environmental Conservation 38:370-379. http://dx.doi. org/10.1017/S0376892911000506

De Groot, R., P. S. Ramakrishnan, A. V. D. Berg, T. Kulenthran, S. Muller, D. Pitt, and D. Wascher. 2005. Chapter 17: cultural and amenity services. Pages 455-476 in R. Hassan, R. Scholes, and N. Ash, editors. Ecosystems and human wellbeing: current state and trends, volume 1. Findings of the Condition and Trends Working Group of the Millennium Ecosystem Assessment. Millennium Ecosystem Assessment Series. Island Press, Washington, D.C., USA. http://dx.doi. org/10.1016/S0167-9309(96)80006-8

De Groot, R. S., R. Alkemade, L. Braat, L. Hein, and L. Willemen. 2010. Challenges in integrating the concept of ecosystem services and values in landscape planning, management and decision making. Ecological Complexity 7:260-272. http://dx.doi.org/10.1016/j.ecocom.2009.10.006

De Groot, R. S., M. A. Wilson, and R. M. J. Boumans. 2002. A typology for the classification, description and valuation of ecosystem functions, goods and services. Ecological Economics 41:393-408. http://dx.doi.org/10.1016/S0921-8009 (02)00089-7

Dick, J., C. Andrews, D. A. Beaumont, S. Benham, D. R. Brooks, S. Corbett, D. Lloyd, S. McMillan, D. T. Monteith, E. S. Pilgrim, R. Rose, A. Scott, T. Scott, R. I. Smith, C. Taylor, M. Taylor, A. Turner, and H. Watson. 2011. A comparison of ecosystem services delivered by 11 long-term monitoring sites in the UK environmental change network. Environmetrics 22:639-648. http://dx.doi.org/10.1002/env.1069

Ding, H. 2009. A hybrid approach to the valuation of climate change effects on ecosystem services: evidence from European forests. Paper presented at the 11th Annual BIOECON Conference on Economic Instruments to Enhance the
Conservation and Sustainable Use of Biodiversity, Centro Culturale Don Orione Artigianelli, Venice, Italy September 21-22, 2009. http://dx.doi.org/10.2139/ssrn.1603826

Ding, H., S. Silvestri, A. Chiabai, and A. L. D. Nunes. 2009. A hybrid approach to the valuation of climate change effects on ecosystem services: evidence from European forests. Paper presented at the 11th Annual BIOECON Conference on Economic Instruments to Enhance the Conservation and Sustainable Use of Biodiversity, Centro Culturale Don Orione Artigianelli, Venice, Italy September 21-22, 2009.

Dominati, E., M. Patterson, and A. Mackay. 2010. A framework for classifying and quantifying the natural capital and ecosystem services of soils. Ecological Economics 69:1858-1868. http://dx.doi.org/10.1016/j.ecolecon.2010.05.002

Edwards, D. M., M. Jay, F. S. Jensen, B. Lucas, M. Marzano, C. Montagné, A. Peace, and G. Weiss. 2012. Public preferences across Europe for different forest stand types as sites for recreation. Ecology and Society 17(1): 27. http://dx. doi.org/10.5751/ES-04520-170127

Egoh, B., M. Rouget, B. Reyers, A. Knight, R. Cowling, A. van Jaarsveld, and A. Welz. 2007. Integrating ecosystem services into conservation assessments: a review. Ecological Economics 63:714-721. http://dx.doi.org/10.1016/j. ecolecon.2007.04.007

Eicken, H., A. L. Lovecraft, and M. L. Druckenmiller. 2009. Sea-ice system services: a framework to help identify and meet information needs relevant for Arctic observing networks. Arctic 62:119-136.

Elmqvist, T., E. Matby, T. Barker, M. Mortimer, C. Perrings, J. Aronson, et al. 2010. Biodiversity, ecosystems and ecosystem services. Pages 1-96 in P. Kumar et al., editors. The economics of ecosystems and biodiversity: ecological and economic foundations. Earthscan, London, UK. http://dx.doi. org/10.1007/978-94-007-7088-1

Enengel, B., C. Mann, R. Williams, M. Penker, and O. Aznar. 2009. Can landscape stewardship be analysed and enhanced through the concept of service economics? Paper presented at First International Conference on Landscape Economics, Vienna, Austria, July 2-4, 2009.

Everard, M., and G. Kataria. 2011. Recreational angling markets to advance the conservation of a reach of the Western Ramganga River, India. Aquatic Conservation: Marine and Freshwater Ecosystems 21:101-108. http://dx.doi.org/10.1002/ aqc. 1159

Everitt, B., S. Landau, and M. Leese. 2001. Cluster analysis. Fourth edition. John Wiley \& Sons, London, UK. http://dx. doi.org/10.1002/9780470977811 
Fagerholm, N., and N. Käyhkö. 2009. Participatory mapping and geographical patterns of the social landscape values of rural communities in Zanzibar, Tanzania. Fennia 187:43-60.

Finnoff, D., M. Gong, and J. Tschirhart. 2012. Perspectives on ecosystem based management for delivering ecosystem services with an example from an eighteen-species marine model. International Review of Environmental and Resource Economics 6(1):79-118. http://dx.doi.org/10.1561/101.00000048

Fischer, J., T. Hartel, and T. Kuemmerle. 2012. Conservation policy in traditional farming landscapes. Conservation Letters 5(3):167-175. http://dx.doi.org/10.1111/j.1755-263X.2012.00227. $\underline{x}$

Fish, D. R. 2011. Environmental decision making and an ecosystems approach: some challenges from the perspective of social science. Progress in Physical Geography 35:671-680. http://dx.doi.org/10.1177/0309133311420941

Fisher, B., R. Turner, and P. Morling. 2009. Defining and classifying ecosystem services for decision making. Ecological Economics 68:643-653. http://dx.doi.org/10.1016/ j.ecolecon.2008.09.014

Gasparatos, A., P. Stromberg, and K. Takeuchi. 2011. Biofuels, ecosystem services and human well-being: putting biofuels in the ecosystem services narrative. Agriculture, Ecosystems \& Environment 142:111-128.

Gee, K., and B. Burkhard. 2010. Cultural ecosystem services in the context of offshore wind farming: a case study from the west coast of Schleswig-Holstein. Ecological Complexity 7:349-358. http://dx.doi.org/10.1016/j.ecocom.2010.02.008

Giannecchini, M., W. Twine, and C. Vogel. 2007. Land-cover change and human-environment interactions in a rural cultural landscape in South Africa. Geographical Journal 173:26-42. http://dx.doi.org/10.1111/j.1475-4959.2007.00227.x

Glotzbach, S. 2012. Environmental justice in agricultural systems: an evaluation of success factors and barriers by the example of the Philippine farmer network MASIPAG. Working Paper Series in Economics No. 225. University of Lüneburg, Lüneburg, Germany.

González, V., L. D. Balteiro, and E. L.-P. Martínez. 2010. Spatial valuation of recreation activities in forest systems: application to province of Segovia (Spain). Forest Systems 19:36-50.

Gordon, L. J., C. M. Finlayson, and M. Falkenmark. 2010. Managing water in agriculture for food production and other ecosystem services. Agricultural Water Management 97:512-519. http://dx.doi.org/10.1016/j.agwat.2009.03.017

Guo, Z., L. Zhang, and Y. Li. 2010. Increased dependence of humans on ecosystem services and biodiversity. PLOS ONE 5 (10):e13113. http://dx.doi.org/10.1371/journal.pone.0013113
Haaland, C., G. Fry, and A. Peterson. 2011. Designing farmland for multifunctionality. Landscape Research 36:41-62. http://dx.doi.org/10.1080/01426397.2010.536202

Haslett, J. R., P. M. Berry, G. Bela, R. H. G. Jongman, G. Pataki, M. J. Samways, and M. Zobel. 2010. Changing conservation strategies in Europe: a framework integrating ecosystem services and dynamics. Biodiversity and Conservation 19:2963-2977. http://dx.doi.org/10.1007/ $\underline{\mathrm{s} 10531-009-9743-\mathrm{y}}$

Hearnshaw, E., and R. Cullen. 2010. The sustainability and cost-effectiveness of water storage projects on Canterbury rivers: the Opihi River case paper. Paper presented at the 2010 NZARES Conference Tahuna Conference Centre, Nelson, New Zealand. August 26-27, 2010.

Hendee, J. T. 2011. Assessing private forest landowner decision making in Illinois: applied management solutions for diverse objectives. Dissertation. University of Illinois at Urbana-Champaign, Illinois, USA.

Hermann, A., S. Schleifer, and T. Wrbka. 2011. The concept of ecosystem services regarding landscape research: a review. Living reviews in Landscape Research 5:1-37. http://dx.doi. org/10.12942/lrlr-2011-1

Holt, A., J. Godbold, P. White, A. Slater, E. Pereira, and M. Solan. 2011. Mismatches between legislative frameworks and benefits restrict the implementation of the ecosystem approach in coastal environments. Marine Ecology Progress Series 434:213-228. http://dx.doi.org/10.3354/meps09260

Ingold, K., and W. Zimmermann. 2011. How and why forest managers adapt to socio-economic changes: a case study analysis in Swiss forest enterprises. Forest Policy and Economics 13:97-103. http://dx.doi.org/10.1016/j.forpol.2010.06.003

Johnston, R. J., and M. Russell. 2011. An operational structure for clarity in ecosystem service values. Ecological Economics 70:2243-2249. http://dx.doi.org/10.1016/j.ecolecon.2011.07.003

Kenter, J. O., T. Hyde, M. Christie, and I. Fazey. 2011. The importance of deliberation in valuing ecosystem services in developing countries - evidence from the Solomon Islands. Global Environmental Change 21:505-521. http://dx.doi. org/10.1016/j.gloenvcha.2011.01.001

Kerr, G. N., and S. R. Swaffield. 2007. Amenity values of spring fed streams and rivers in Canterbury, New Zealand: a methodological exploration. Research Report No. 298. The Agribusiness and Economics Research Unit (AERU), Lincoln University, Lincoln, UK.

Khan, M. L., A. D. Khumbongmayum, and R. S. Tripathi. 2008. The sacred groves and their significance in conserving biodiversity: an overview. International Journal of Ecology and Environmental Sciences 34:277-291. 
Kimmel, K., and U. Mander. 2010. Ecosystem services of peatlands: implications for restoration. Progress in Physical Geography 34:491-514. http://dx.doi.org/10.1177/0309133310365595

Klain, S. 2010. Navigating marine ecosystems services and values. Master of Science thesis. Faculty of Graduate Studies, Resource Management and Environmental Studies, University of British Columbia, Vancouver, British Columbia, Canada.

Kløve, B., A. Allan, G. Bertrand, E. Druzynska, A. Ertürk, N. Goldscheider, S. Henry, N. Karakaya, T. P. Karjalainen, P. Koundouri, H. Kupfersberger, J. Kvœrner, A. Lundberg, T. Muotka, E. Preda, M. Pulido Velázquez, and P. Schipper. 2011. Groundwater dependent ecosystems. Part II. Ecosystem services and management in Europe under risk of climate change and land use intensification. Environmental Science \& Policy 14:782-793.

Kowarik, I., L.K. Fischer, I. Säumel, M. von der Lippe, F. Weber, and J. R. Westermann 2011. Plants in urban settings: from patterns to mechanisms and ecosystem service. Pages 135-166 in E. Wilfried, et al., editors. Perspectives in urban ecology. Springer Berlin, Heidelberg, Germany. http://dx.doi. org/10.1007/978-3-642-17731-6 5

Kumar, M., and P. Kumar. 2008. Valuation of the ecosystem services: a psycho-cultural perspective. Ecological Economics 64:808-819. http://dx.doi.org/10.1016/j. ecolecon.2007.05.008

Kumar, P., editor. 2010. The economics of ecosystems and biodiversity: ecological and economic foundations. The Economics of Ecosystems and Biodiversity (TEEB), United Nations Environment Programme, Geneva, Switzerland.

Kunz, T. H., E. B. de Torrez, D. Bauer, T. Lobova, and T. H. Fleming. 2011. Ecosystem services provided by bats. Annals of the New York Academy of Sciences 1223:1-38. http://dx.doi. org/10.1111/j.1749-6632.2011.06004.x

Lamarque, P., F. Quetier, and S. Lavorel. 2011. The diversity of the ecosystem services concept and its implications for their assessment and management. Compte-Rendus de l'Académie des Sciences, Biologie 334:441-449. http://dx.doi.org/10.1016/ j.crvi.2010.11.007

Lautenbach, S., C. Kugel, A. Lausch, and R. Seppelt. 2011. Analysis of historic changes in regional ecosystem service provisioning using land use data. Ecological Indicators 11:676-687.http://dx.doi.org/10.1016/j.ecolind.2010.09.007

Leadley, P., H. M. Pereira, R. Alkemade, J. F. FernandezManjarrés, V. Proença, J. P. W. Scharlemann, and M. J. Walpole. 2010. Biodiversity scenarios: projections of $21^{\text {st }}$ century change in biodiversity and associated ecosystem services. Technical Series No. 50. Secretariat of the Convention on Biological Diversity, Montreal, Canada.

Le Maitre, D. C., P. J. O'Farrell, and B. Reyers. 2007. Ecosystems services in South Africa: a research theme that can engage environmental, economic and social scientists in the development of sustainability science? South African Journal of Science 103:367-376.

Liu, S., R. Constanza, S. Farber, and A. Troy. 2010. Valuing ecosystem services: theory, practice, and the need for a transdisciplinary synthesis. Annals of the New York Academy of Sciences 1185:54-78. http://dx.doi.org/10.1111/ j.1749-6632.2009.05167.x

Ljung, K., F. Maley, A. Cook, and P. Weinstein. 2009. Acid sulfate soils and human health-a Millennium Ecosystem Assessment. Environment International 35:1234-1242. http:// dx.doi.org/10.1016/j.envint.2009.07.002

López-Hoffman, L., R. G. Varady, K. W. Flessa, and P. Balvanera. 2010. Ecosystem services across borders: a framework for transboundary conservation policy. Frontiers in Ecology and the Environment 8:84-91. http://dx.doi. org/10.1890/070216

Lundy, L., and R. Wade. 2011. Integrating sciences to sustain urban ecosystem services. Progress in Physical Geography 35:653-669. http://dx.doi.org/10.1177/0309133311422464

Maass, J., P. Balvanera, A. Castillo, G. C. Daily, H. A. Mooney, P. Ehrlich, M. Quesada, A. Miranda, V. J. Jaramillo, F. García-Oliva, A. Martínez-Yrizar, H. Cotler, J. LópezBlanco, A. Pérez-Jiménez, A. Búrquez, C. Tinoco, G. Ceballos, L. Barraza, R. Ayala, and J. Sarukhán. 2005. Ecosystem services of tropical dry forests: insights from longterm ecological and social research on the Pacific Coast of Mexico. Ecology and Society 10(1): 17. [online] URL: http:// www.ecologyandsociety.org/vol10/iss1/art17/

Martín-López, B., E. Gómez-Baggethun, P. L. Lomas, and C. Montes. 2009. Effects of spatial and temporal scales on cultural services valuation. Journal of Environmental Management 90:1050-1059. http://dx.doi.org/10.1016/j. jenvman.2008.03.013

Moore, T., and W. F. Hunt. 2012. Ecosystem service provision by Stormwater Wetlands and Ponds-a means for evaluation? Water Research 46(20):6811-6823.

Nainggolan, D., M. Termansen, M. S. Reed, E. D. Cebollero, and K. Hubacek. 2011. Farmer typology, future scenarios and the implications for ecosystem service provision: a case study from south-eastern Spain. Regional Environmental Change 13(3):601-614. http://dx.doi.org/10.1007/s10113-011-0261-6 
Niemelä, J., S.-R. Saarela, T. Söderman, L. Kopperoinen, V. Yli-Pelkonen, S. Väre, and D. J. Kotze. 2010. Using the ecosystem services approach for better planning and conservation of urban green spaces: a Finland case study. Biodiversity and Conservation 19:3225-3243. http://dx.doi. org/10.1007/s10531-010-9888-8

Norton, L. R., H. Inwood, A. Crowe, and A. Baker. 2012. Trialling a method to quantify the 'cultural services' of the English landscape using Countryside Survey data. Land Use Policy 29:449-455. http://dx.doi.org/10.1016/j.landusepol.2011.09.002

Palomo, I., B. Martín-López, C. López-Santiago, and C. Montes. 2011. Participatory scenario planning for protected areas management under the ecosystem services framework: the doñana social-ecological system in southwestern spain. Ecology and Society 16(1): 23. [online] URL: http://www. ecologyandsociety.org/vol16/iss1/art23/

Plieninger, T., S. Dijks, E. Oteros-Rozas, and C. Bieling. 2013. Assessing, mapping and quantifying cultural ecosystem services at the community level. Land Use Policy 33:118-129. http://dx.doi.org/10.1016/j.landusepol.2012.12.013

Power, A. G. 2010. Ecosystem services and agriculture: tradeoffs and synergies. Philosophical Transactions of the Royal Society of London 365:2959-2971. http://dx.doi. org/10.1098/rstb.2010.0143

Quétier, F., F. Rivoal, P. Marty, J. Chazal, W. Thuiller, and S. Lavorel. 2010. Social representations of an alpine grassland landscape and socio-political discourses on rural development. Regional Environmental Change 10:119-130. http://dx.doi.org/10.1007/s10113-009-0099-3

Raudsepp-Hearne, C., G. D. Peterson, and E. M. Bennett. 2010a. Ecosystem service bundles for analyzing tradeoffs in diverse landscapes. Proceedings of the National Academy of Sciences of the United States of America 107:5242-5247.

Raudsepp-Hearne, C., G. D. Peterson, M. Tengö, E. M. Bennett, T. Holland, K. Benessaiah, G. K. MacDonald, and L. Pfeifer. 2010b. Untangling the environmentalist's paradox: why is human well-being increasing as ecosystem services degrade? BioScience 60:576-589.

Raymond, C. M., B. A. Bryan, D. Hatton, A. Cast, S. Strathearn, A. Grandgirard, and T. Kalivas. 2009. Mapping community values for natural capital and ecosystem services. Ecological Economics 68:1301-1315. http://dx.doi.org/10.1016/ j.ecolecon.2008.12.006

Rodríguez, J. P., T. D. Beard, Jr., E. M. Bennett, G. S. Cumming, S. Cork, J. Agard, A. P. Dobson, and G. D. Peterson. 2006. Trade-offs across space, time, and ecosystem services. Ecology and Society 11(1): 28. [online] URL: http://www. ecologyandsociety.org/vol11/iss1/art28/
Rössler, M. 2006. World heritage cultural landscapes: a UNESCO flagship programme 1992-2006. Landscape Research 31:333-353. http://dx.doi.org/10.1080/01426390601004210

Rounsevell, M. D. A., T. P. Dawson, and P. A. Harrison. 2010. A conceptual framework to assess the effects of environmental change on ecosystem services. Biodiversity and Conservation 19:2823-2842. http://dx.doi.org/10.1007/s10531-010-9838-5

Sarukhán, J., and A. Whyte, editors. 2003. Ecosystems and human well-being: a framework for assessment. Millennium Ecosystem Assessment Series. A report of the Conceptual Framework Working Group of the Millennium Ecosystem Working Group. Island Press, Washington, D.C., USA.

Sarukhán, J., and A. Whyte, editors. 2005. Ecosystems and human well-being: Synthesis (Millennium Ecosystem Assessment). Island Press, World Resources Institute, Washington, D.C., USA.

Schaich, H., C. Bieling, and T. Plieninger. 2010. Linking ecosystem services with cultural landscape research. Gaia 19:269-277.

Schröter, D. 2005. Vulnerability to changes in ecosystem services. Working Paper No. 10. Center for International Development at Harvard University, Cambridge, Massachusetts, USA. http://dx.doi.org/10.1126/science.1115233

Scullion, J., C. W. Thomas, K. A. Vogt, O. Pérez-Maqueo, and M. G. Logsdon. 2011. Evaluating the environmental impact of payments for ecosystem services in Coatepec (Mexico) using remote sensing and on-site interviews. Environmental Conservation 38:426-434. http://dx.doi. org/10.1017/S037689291100052X

Seppelt, R., C. F. Dormann, F. V. Eppink, S. Lautenbach, and S. Schmidt. 2011. A quantitative review of ecosystem service studies: approaches, shortcomings and the road ahead. Journal of Applied Ecology 48:630-636. http://dx.doi.org/10.1111/ j.1365-2664.2010.01952.X

Seppelt, R., B. Fath, B. Burkhard, J. L. Fisher, A. GrêtRegamey, S. Lautenbach, P. Pert, S. Hotes, J. Spangenberg, P. H. Verburg, and A. P. E. Van Oudenhoven. 2012. Form follows function? Proposing a blueprint for ecosystem service assessments based on reviews and case studies. Ecological Indicators 21:145-154. http://dx.doi.org/10.1016/j. ecolind.2011.09.003

Sherren, K., J. Fischer, and R. Price. 2010. Using photography to elicit grazier values and management practices relating to tree survival and recruitment. Land Use Policy 27:1056-1067. http://dx.doi.org/10.1016/j.landusepol.2010.02.002

Sherrouse, B. C., J. M. Clement, and D. J. Semmens. 2011. A GIS application for assessing, mapping, and quantifying the 
social values of ecosystem services. Applied Geography 31:748-760. http://dx.doi.org/10.1016/j.apgeog.2010.08.002

Smith, N., R. Deal, J. Kline, D. Blahna, T. Patterson, T. A. Spies, and K. Bennett. 2011. Ecosystem services as a framework for forest stewardship: Deschutes National Forest overview. General Technical Report PNW-GTR-852. Pacific Northwest Research Station, Forest Service, United States Department of Agriculture, Portland, Oregon, USA.

Soini, K., H. Vaarala, and E. Pouta. 2012. Residents' sense of place and landscape perceptions at the rural-urban interface. Landscape and Urban Planning 104:124-134. http://dx.doi. org/10.1016/j.landurbplan.2011.10.002

Sukhdev, P., H. Wittmer, C. Schröter-Schlaack, C. Nesshöver, J. Bishop, P. ten Brink, H. Gundimeda, P. Kumar, and B. Simmons. 2010. The economics of ecosystems and biodiversity, mainstreaming the economics of nature: a synthesis of the approach, conclusions and recommendations of TEEB. The Economics of Ecosystems and Biodiversity (TEEB), United Nations Environment Programme, Geneva, Switzerland.

Swinton, S. M., F. Lupi, G. P. Robertson, and S. K. Hamilton. 2007. Ecosystem services and agriculture: cultivating agricultural ecosystems for diverse benefits. Ecological Economics 64:245-252. http://dx.doi.org/10.1016/j. ecolecon.2007.09.020

Termorshuizen, J. W., and P. Opdam. 2009. Landscape services as a bridge between landscape ecology and sustainable development. Landscape Ecology 24:1037-1052. http://dx.doi.org/10.1007/s10980-008-9314-8

Tielbörger, K., A. Fleischer, L. Menzel, J. Metz, and M. Sternberg. 2010. The aesthetics of water and land: a promising concept for managing scarce water resources under climate change. Philosophical Transactions of the Royal Society 368:5323-5337. http://dx.doi.org/10.1098/rsta.2010.0143

Tolentino, A. S. 2007. Wetland cultural heritage in the Pacific. International Review for Environmental Strategies 7:155-162.

Tompkins, J.-M., E. J. Hearnshaw, and R. Cullen. 2011. Evaluating the sustainability of impounded river systems and the cost-effectiveness of dam projects: an ecosystem services approach. Paper presented at 55th Annual Australian Agricultural and Resource Economics Society National Conference, Melbourne, Victoria, Australia, February 8-11, 2011.

Turner, K. 2010. A pluralistic approach to ecosystem services evaluation. CSERGE Working Paper EDM 10-07. The Centre for Social and Economic Research on the Global Environment (CSERGE), Norwich, UK.

Tzoulas, K., and P. James. 2010. Peoples' use of, and concerns about, green space networks: a case study of Birchwood,
Warrington New Town, UK. Urban Forestry \& Urban Greening 9:121-128. http://dx.doi.org/10.1016/j.ufug.2009.12.001

Vandewalle, M., M. T. Sykes, P. A. Harrison, G. W. Luck, P. Berry, R. Bugter, T. P. Dawson, C. K. Feld, R. Harrington, J. R. Haslett, D. Hering, K. B. Jones, R. Jongman, S. Lavorel, P. Martins da Silva, M. Moora, J. Paterson, M.D.A. Rounsevell, L. Sandin, J. Settele, J. P. Sousa, and M. Zobel. 2008. Review paper on concepts of dynamic ecosystems and their services. RUBICODE Project-Rationalising Biodiversity Conservation in Dynamic Ecosystems. Funded under the European Commission Sixth Framework Programme.

Vejre, H., F. S. Jensen, and B. J. Thorsen. 2010. Demonstrating the importance of intangible ecosystem services from periurban landscapes. Ecological Complexity 7:338-348. http:// dx.doi.org/10.1016/j.ecocom.2009.09.005

Viglizzo, E. F., J. M. Paruelo, P. Laterra, and E. G. Jobbágy. 2012. Ecosystem service evaluation to support land-use policy. Agriculture, Ecosystems \& Environment 154:78-84. http://dx.doi.org/10.1016/j.agee.2011.07.007

Vihervaara, P., T. Kumpula, A. Tanskanen, and B. Burkhard. 2010a. Ecosystem services-a tool for sustainable management of human-environment systems. Case study Finnish Forest Lapland. Ecological Complexity 7:410-420.

Vihervaara, P., M. Rönkä, and M. Walls. 2010b. Trends in ecosystem service research: early steps and current drivers. AMBIO 39:314-324.

Voora, V., and S. Barg. 2008. Pimachiowin Aki World Heritage Project Area ecosystem services valuation assessment. International Institute for Sustainable Development (IISD), Winnipeg, Manitoba, Canada.

Wallace, K. J. 2007. Classification of ecosystem services: problems and solutions. Biological Conservation 39:235-246. http://dx.doi.org/10.1016/j.biocon.2007.07.015

Wang, Z., J. I. Nassauer, R. W. Marans, and D. G. Brown. 2012. Different types of open spaces and their importance to exurban homeowners. Society \& Natural Resources 25 (4):368-383. http://dx.doi.org/10.1080/08941920.2011.571231

Whitfield, S., M. Reed, K. Thomson, M. Christie, L. C. Stringer, C. H. Quinn, R. Anderson, A. Moxey, and K. Hubacek. 2011. Managing peatland ecosystem services: current UK policy and future challenges in a changing world. Scottish Geographical Journal 127:209-230.

Williams, K., and J. Cary. 2001. Perception of native grasslands in south-eastern Australia. Ecological Management and Restoration 2:139-144. http://dx.doi.org/10.1046/ j.1442-8903.2001.00077.x

Wittmer, H., A. Berghöfer, J. Förster, and K. Almack. 2010. The economics of ecosystems and biodiversity for local and 
regional policy makers. The Economics of Ecosystems and Biodiversity (TEEB), United Nations Environment Programme, Geneva, Switzerland.

Yeo-Chang, Y. 2009. Use of forest resources, traditional forest-related knowledge and livelihood of forest dependent communities: cases in South Korea. Forest Ecology and Management 257:2027-2034. http://dx.doi.org/10.1016/j. foreco.2009.01.054

Zander, K. K., S. T. Garnett, and A. Straton. 2010. Trade-offs between development, culture and conservation-willingness to pay for tropical river management among urban Australians. Journal of Environmental Management 91:2519-2528. http:// dx.doi.org/10.1016/j.jenvman.2010.07.012

Zhang, Y., S. Singh, and B. R. Bakshi. 2010. Accounting for ecosystem services in life cycle assessment, Part I: a critical review. Environmental Science \& Technology 44:2232-2242. http://dx.doi.org/10.1021/es9021156 


\section{Appendix 1}

Table A1.1. List of the 107 papers considered in this review.

\section{Paper}

Type of paper

1. Abson, D. J., and M. Termansen. 2011. Valuing ecosystem services in terms of ecological risks and returns. Conservation Biology 25:250-258.

2. Adekola, O., and G. Mitchell. 2011. The Niger Delta wetlands: threats to ecosystem services, their importance to dependent communities and possible management measures. International Journal of Biodiversity Science, Ecosystem Services \& Management 7:50-68.

3. Beaumont, N. J., M. C. Austen, S. C. Mangi, and M. Townsend. 2008. Economic valuation for the conservation of marine biodiversity. Marine Pollution Bulletin 56:386-396.

4. Bohensky, E., J. R. A. Butler, R. Costanza, I. Bohnet, A. Delisle, K. Fabricius, M. Gooch, I. Kubiszewski, G. Lukacs, P. Pert, and E. Wolanski. 2011. Future makers or future takers? A scenario analysis of climate change and the Great Barrier Reef. Global Environmental Change 21:876-893.

5. Boyd, J., and S. Banzhaf. 2007. What are ecosystem services? The need for standardized environmental accounting units. Ecological Economics 63:616-626.

6. Brown, G., J. M. Montag, and K. Lyon. 2012. Public Participation GIS: A Method for Identifying Ecosystem Services. Society \& Natural Resources 25:633-651.

7. Brown, J., and M. Neil. 2011. A site-based approach to delivering rangeland ecosystem services. The Rangeland Journal 33:99-108.

8. Bullock, C. H., and M. Collier. 2011. When the public good conflicts with an apparent preference for unsustainable behaviour. Ecological Economics 70:971977.

9. Burgess, P. J., A. J. Moffat, and R. B. Matthews. 2010. Assessing climate

Journal article

Journal article

Journal article

Journal article

Journal article

Journal article

Journal article

Journal article

Journal article 
change causes, risks and opportunities in forestry. Outlook on Agriculture 39:263-268.

10. Burkhard, B., B. D. Fath, and F. Müller. 2011. Adapting the adaptive cycle: Hypotheses on the development of ecosystem properties and services. Ecological Modelling 222:2878-2890.

11. Burkhard, B., F. Kroll, S. Nedkov, and F. Müller. 2012. Mapping ecosystem service supply, demand and budgets. Ecological Indicators 21:17-29.

12. Busch, M., K. Gee, B. Burkhard, M. Lange, and N. Stelljes. 2011. Conceptualizing the link between marine ecosystem services and human wellbeing: the case of offshore wind farming. International Journal of Biodiversity Science, Ecosystem Services \& Management 7:190-203.

13. Busch, M., A. La Notte, V. Laporte, and M. Erhard. 2012. Potentials of quantitative and qualitative approaches to assessing ecosystem services. Ecological Indicators 21:89-103.

14. Butler, C. D., and W. Oluoch-Kosura. 2006. Linking Future Ecosystem Services and Future Human Well-being. Ecology and Society 11:30.

15. Carpenter, S. R., H. A. Mooney, J. Agard, D. Capistrano, R. S. DeFries, S. Díaz, T. Dietz, A. K. Duraiappah, A. Oteng-Yeboah, H. Miguel, C. Perrings, R. J. Scholes, A. Whyte, and W. V. Reid. 2009. Science for managing ecosystem services: Beyond the Millennium Ecosystem Assessment. Proceedings of the National Academy of Sciences of the United States of America 106:1305-1312.

16. Chan, K. M. A., and M. Ruckelshaus. 2010. Characterizing changes in marine ecosystem services. F1000 Biology Reports 2:54.

17. Chan, K. M. A., J. Goldstein, T. Satterfield, N. Hannahs, K. Kikiloi, R. Naidoo, N. Vadeboncoeur and U. Woodside. 2011. Cultural services and non-use values. Pages 206-228 in P. Kareiva, H. Tallis, T. H. Ricketts, G. C. Daily and S. Polasky, editors. Natural Capital: Theory \& Practice of Mapping Ecosystem Services. Oxford University Press, Oxford, UK.

18. Chan, K. M. A., T. Satterfield, and J. Goldstein. 2012. Rethinking ecosystem services to better address and navigate cultural values. Ecological Economics

Journal article

Journal article

Journal article

Journal article

Journal article

Journal article

Journal article

Book chapter

Journal article 
74:8-18.

19. Chapin, F. S., III, A. L. Lovecraft, E. S. Zavaleta, J. Nelson, M. D. Robards, G. P. Kofinas, S. F. Trainor, G. D. Peterson, H. P. Huntington, and R. L. Naylor. 2006. Policy strategies to address sustainability of Alaskan boreal forests in response to a directionally changing climate. Proceedings of the National Academy of Sciences of the United States of America 103:16637-16643.

20. Charles, H. and J. S. Dukes. 2007. Impacts of Invasive Species on Ecosystem Services. Pages 217-237 in W. Nentwig, editor. Biological Invasions Springer, Berlin, Germany.

21. Chiabai, A., C. M. Travisi, H. Ding, A. Markandya, and P. A. L. D. Nunes. 2009. Economic Valuation of Forest Ecosystem Services: Methodology and Monetary Estimates. Fondazione Eni Enrico Mattei. EU funded project COPI "Cost of Policy Inaction".

22. Chiabai, A., C. M. Travisi, A. Markandya, H. Ding, and P. A. L. D. Nunes. 2011. Economic Assessment of Forest Ecosystem Services Losses: Cost of Policy Inaction. Environmental and Resource Economics 50:405-445.

23. Cooley, S. 2009. Ocean Acidification's potential to alter Global Marine Ecosystem Services. Oceanography 22:172-181.

24. Daily, G. C., S. Polasky, J. Goldstein, P. M. Kareiva, H. A. Mooney, L. Pejchar T. H. Ricketts, J. Salzman, and R. Shallenberger. 2009. Ecosystem services in decision making: time to deliver. Frontiers in Ecology and the Environment 7:21-28.

25. Dick, J., C. Andrews, D. A. Beaumont, S. Benham, D. R. Brooks, S. Corbett, D. Lloyd, S. McMillan, D. T. Monteith, E. S. Pilgrim, R. Rose, A. Scott, T. Scott, R. I. Smith, C. Taylor, M. Taylor, A. Turner, and H. Watson. 2011. A comparison of ecosystem services delivered by 11 long-term monitoring sites in the UK environmental change network. Environmetrics 22:639-648.

26. Ding, H. 2009. A hybrid approach to the valuation of climate change effects on ecosystem services: evidence from European forests. $11^{\text {th }}$ Annual BIOECON Conference on Economic Instruments to Enhance the Conservation and

Journal article

Journal article

Report

Journal article

Journal article

Journal article

Journal article

Full paper presented at conferences 
Sustainable Use of Biodiversity", Venice, Italy.

27. Dominati, E., M. Patterson, and A. Mackay. 2010. A framework for classifying and quantifying the natural capital and ecosystem services of soils. Ecological Economics 69:1858-1868.

28. Edwards, D., M. Jay, F. S. Jensen, B. Lucas, M. Marzano, C. Montagné, A. Peace, and G. Weiss. 2012. Public Preferences across Europe for Different Forest Stand Types as Sites for Recreation. Ecology and Society 17:27.

29. Egoh, B., M. Rouget, B. Reyers, A. Knight, R. Cowling, A. van Jaarsveld, and A. Welz. 2007. Integrating ecosystem services into conservation assessments: A review. Ecological Economics 63:714-721.

30. Eicken, H., A. L. Lovecraft, and M. L. Druckenmiller. 2009. Sea-ice system services: A framework to help identify and meet information needs relevant for Arctic observing networks. Arctic 62:119-136.

31. Elmqvist, T., E. Matby, T. Barker, M. Mortimer, C. Perrings, J. Aronson, et al. 2010. Biodiversity, ecosystems and ecosystem services. Pages 1-96 in P. Kumar et al., editors. The Economics of Ecosystems and Biodiversity: Ecological and Economic Foundations. Earthscan, London, UK.

32. Finnoff, D., M. Gong, and J. Tschirhart. 2012. Perspectives on Ecosystem based management of eighteen-species subject to multi-species harvesting. International Review of Environmental and Resource Economics 6:79-118.

33. Fish, D. R. 2011. Environmental decision making and an ecosystems approach: Some challenges from the perspective of social science. Progress in Physical Geography 35:671-680.

34. Gasparatos, A., P. Stromberg, and K. Takeuchi. 2011. Biofuels, ecosystem services and human well-being: Putting biofuels in the ecosystem services narrative. Agriculture, Ecosystems \& Environment 142:111-128.

35. Gee, K., and B. Burkhard. 2010. Cultural ecosystem services in the context of offshore wind farming: A case study from the west coast of Schleswig-Holstein. Ecological Complexity 7:349-358.

36. Glotzbach, S. 2012. Environmental justice in agricultural systems. An evaluation

Journal article

Journal article

Journal article

Journal article

Book chapter

Journal article

Journal article

Journal article

Journal article

Working paper 
of success factors and barriers by the example of the Philippine farmer network MASIPAG. Working Paper Series in Economics No. 225, University of

Lüneburg, Lüneburg, Germany.

37. González, V., L. D. Balteiro, and E. L.-P. Martínez. 2010. Spatial valuation of recreation activities in forest systems: application to province of Segovia (Spain). Forest Systems 19:36-50.

38. de Groot, R., P. S. Ramakrishnan, A. V. D. Berg, T. Kulenthran, S. Muller, D. Pitt, and D. Wascher. 2005. Cultural and Amenity Services (Chapter 17). Pages 455-476 in Ecosystems and Human Well-Being: Current State and Trends Assessment. Findings of the Condition and Trends Working Group. Millennium Ecosystem Assessment. Island Press, Washington, D.C., USA.

39. de Groot, R. S., R. Alkemade, L. Braat, L. Hein, and L. Willemen. 2010. Challenges in integrating the concept of ecosystem services and values in landscape planning, management and decision making. Ecological Complexity 7:260-272.

40. Guo, Z., L. Zhang, and Y. Li. 2010. Increased dependence of humans on ecosystem services and biodiversity. PLoS ONE 5(11):e13113.

41. Hagen, B. 2010. The critical natural capital of the Buffalo city municipality, South Africa: harnessing local action for biodiversity conservation. Master. Rhodes University, Grahamstown, South Africa.

42. Harrison, P. A., M. Vandewalle, M. T. Sykes, P. M. Berry, R. Bugter, F. Bello, C. K. Feld, U. Grandin, R. Harrington, J. R. Haslett, R. H. G. Jongman, G. W. Luck, P. M. Silva, M. Moora, J. Settele, J. P. Sousa, and M. Zobel. 2010. Identifying and prioritising services in European terrestrial and freshwater ecosystems. Biodiversity and Conservation 19:2791-2821.

43. Hearnshaw, E., and R. Cullen. 2010a. The Sustainability and Cost-Effectiveness of Water Storage Projects on Canterbury Rivers: The Opihi River Case Paper.in New Zeeland Agricultural and Resource Economics Society Conference, Nelson, New Zeeland.

44. Hearnshaw, E., R. Cullen, and K. Hughey. 2010b. Ecosystem services review of

Journal article

MA chapter

Journal article

Journal article

Master thesis

Journal article

Full paper presented at conferences

Full paper presented at 

of Illinois at Urbana-Champaign, Urbana, Illinois, USA.

46. Hermann, A., S. Schleifer, and T. Wrbka. 2011. The Concept of Ecosystem Services Regarding Landscape Research: A Review. Living reviews in Landscape Research 5:1-37.

47. Holt, A., J. Godbold, P. White, A. Slater, E. Pereira, and M. Solan. 2011. Mismatches between legislative frameworks and benefits restrict the implementation of the Ecosystem Approach in coastal environments. Marine Ecology Progress Series 434:213-228.

48. Home, R. 2009. The social value of urban nature in Switzerland. PhD. Universität Zürich, Zürich, Switzerland.

49. Ingold, K., and W. Zimmermann. 2011. How and why forest managers adapt to socio-economic changes: A case study analysis in Swiss forest enterprises. Forest Policy and Economics 13:97-103.

50. Iwata, Y., K. Fukamachi, and Y. Morimoto. 2011. Public perception of the cultural value of Satoyama landscape types in Japan. Landscape and Ecological Engineering 7:173-184.

51. Jakubowski, A. R., M. D. Casler, and R. D. Jackson. 2010. The Benefits of Harvesting Wetland Invaders for Cellulosic Biofuel: an Ecosystem Services Perspective. Restoration Ecology 18:789-795.

52. Kenter, J. O., T. Hyde, M. Christie, and I. Fazey. 2011. The importance of deliberation in valuing ecosystem services in developing countries — Evidence from the Solomon Islands. Global Environmental Change 21:505-521.

53. Kimmel, K., and U. Mander. 2010. Ecosystem services of peatlands: Implications for restoration. Progress in Physical Geography 34:491-514.

54. Klain, S. 2010. Navigating Marine Ecosystems Services and Values. Master. University of British Columbia, Vancouver, British Columbia, Canada. 
55. Kløve, B., A. Allan, G. Bertrand, E. Druzynska, A. Ertürk, N. Goldscheider, S. Henry, N. Karakaya, T. P. Karjalainen, P. Koundouri, H. Kupfersberger, J.

Kvœrner, A. Lundberg, T. Muotka, E. Preda, M. Pulido Velázquez, and P.

Schipper. 2011. Groundwater dependent ecosystems. Part II. Ecosystem services and management in Europe under risk of climate change and land use intensification. Environmental Science \& Policy 14:782-793.

56. Kowarik, I., L.K. Fischer, I. Säumel, M. von der Lippe, F. Weber and J. R.

Westermann 2011. Plants in Urban Settings: From Patterns to Mechanisms and Ecosystem Service. Pages 135-166 in E. Wilfried, et al., editors. Perspectives in Urban Ecology. Springer Berlin, Heidelberg, Germany.

57. Kunz, T. H., E. B. de Torrez, D. Bauer, T. Lobova, and T. H. Fleming. 2011. Ecosystem services provided by bats. Annals of the New York Academy of Sciences 1223:1-38

58. Lautenbach, S., C. Kugel, A. Lausch, and R. Seppelt. 2011. Analysis of historic changes in regional ecosystem service provisioning using land use data. Ecological Indicators 11:676-687.

59. Layke, C., A. Mapendembe, C. Brown, M. Walpole, and J. Winn. 2012. Indicators from the global and sub-global Millennium Ecosystem Assessments: An analysis and next steps. Ecological Indicators 17:77-87.

60. Leadley, P., H.M. Pereira, R. Alkemade, J.F. Fernandez-Manjarrés, V. Proença, J.P.W. Scharlemann and M.J. Walpole. 2010. Biodiversity Scenarios:

Projections of $21^{\text {st }}$ century change in biodiversity and associated ecosystem services. Technical Series no. 50. Secretariat of the Convention on Biological Diversity, Montreal, Canada.

61. Ljung, K., F. Maley, A. Cook, and P. Weinstein. 2009. Acid sulfate soils and human health - A Millennium Ecosystem Assessment. Environment International 35:1234-1242.

62. López-Hoffman, L., R. G. Varady, K. W. Flessa, and P. Balvanera. 2010. Ecosystem services across borders: a framework for transboundary conservation policy. Frontiers in Ecology and the Environment 8:84-91.
Journal article

Book chapter

Journal article

Journal article

Journal article

Report

Journal article

Journal article 
63. Lundy, L. and R. Wade. 2011. Integrating sciences to sustain urban ecosystem services. Progress in Physical Geography 35:653-669.

64. Maass, M., P. Balvanera, A. Castillo, G. C. Daily, H. A. Mooney, P. Ehrlich, M. Quesada, A. Miranda, V. J. Jaramillo, F. García-Oliva, A. Martínez-Yrizar, H.

Cotler, J. López-Blanco, A. Pérez-Jiménez, A. Búrquez, C. Tinoco, G. Ceballos, L. Barraza, and R. Ayala. 2005. Ecosystem Services of Tropical Dry Forests: Insights from Long- term Ecological and Social Research on the Pacific Coast of Mexico. Ecology and Society 10:17.

65. le Maitre, D. C., P. J. O'Farrell, and B. Reyers. 2007. Ecosystems services in South Africa: a research theme that can engage environmental, economic and social scientists in the development of sustainability science? South African Journal of Science 103:367-376.

66. Martín-López, B., E. Gómez-Baggethun, P. L. Lomas, and C. Montes. 2009. Effects of spatial and temporal scales on cultural services valuation. Journal of Environmental Management 90:1050-1059.

67. Martín-López, B., M. García-Llorente, I. Palomo, and C. Montes. 2011. The conservation against development paradigm in protected areas: Valuation of ecosystem services in the Doñana social-ecological system (southwestern Spain). Ecological Economics 70:1481-1491.

68. Moore, T. 2011. Assessment of Ecosystem Service Provision by Stormwater Control Measures. PhD. North Carolina State University, Raleigh, North Carolina, USA.

69. Moore, T., and W. F. Hunt. 2012. Ecosystem Service Provision by Stormwater Wetlands and Ponds - A Means for Evaluation? Water Research 46(20):68116823.

70. Nainggolan, D., M. Termansen, M. S. Reed, E. D. Cebollero, and K. Hubacek. 2011. Farmer typology, future scenarios and the implications for ecosystem service provision: a case study from south-eastern Spain. Regional Environmental Change, (DOI) 10.1007/s10113-011-0261-6.

71. Niemelä, J., S.-R. Saarela, T. Söderman, L. Kopperoinen, V. Yli-Pelkonen, S.

Journal article

Journal article

Journal article

Journal article

Journal article

$\mathrm{PhD}$ thesis

Journal article

Journal article

Journal article 
Väre, and D. J. Kotze. 2010. Using the ecosystem services approach for better planning and conservation of urban green spaces: A Finland case study. Biodiversity and Conservation 19:3225-3243.

72. Norton, L. R., H. Inwood, A. Crowe, and A. Baker. 2012. Trialing a method to quantify the 'cultural services' of the English landscape using Countryside Survey data. Land Use Policy 29:449-455.

73. Palomo, I., and C. Montes. 2011. Participatory Scenario Planning for Protected Areas Management under the Ecosystem Services Framework: the Doñana Social-Ecological System in Southwestern Spain. Ecology and Society 16:23.

74. Pejchar, L., and H. A. Mooney. 2009. Invasive species, ecosystem services and human well-being. Trends in Ecology \& Evolution 24:497-504.

75. van Poorten, B. T., R. Arlinghaus, K. Daedlow, and S. S. Haertel-Borer. 2011. Social-ecological interactions, management panaceas, and the future of wild fish populations. Proceedings of the National Academy of Sciences of the United States of America 108:12554-12559.

76. Power, A. G. 2010. Ecosystem services and agriculture: tradeoffs and synergies. Philosophical Transactions of the Royal Society of London. 365:2959-2971.

77. Prévot-Julliard, A.-C., J. Clavel, P. Teillac-Deschamps, and R. Julliard. 2011. The need for flexibility in conservation practices: exotic species as an example. Environmental Management 47:315-321.

78. Quétier, F., F. Rivoal, P. Marty, J. Chazal, W. Thuiller, and S. Lavorel. 2010. Social representations of an alpine grassland landscape and socio-political discourses on rural development. Regional Environmental Change 10:119-130.

79. Raudsepp-Hearne, C., G. D. Peterson, and E. M. Bennett. 2010a. Ecosystem service bundles for analyzing tradeoffs in diverse landscapes. Proceedings of the National Academy of Sciences of the United States of America 107:5242-5247.

80. Raudsepp-Hearne, C., G. D. Peterson, M. Tengö, E. M. Bennett, T. Holland, K. Benessaiah, G. K. MacDonald, and L. Pfeifer. 2010b. Untangling the Environmentalist's Paradox: Why Is Human Well-being Increasing as Ecosystem Services Degrade? BioScience 60:576-589.

Journal article

Journal article

Journal article

Journal article

Journal article

Journal article

Journal article

Journal article

Journal article 
81. Raymond, C. M., B. A. Bryan, D. Hatton, A. Cast, S. Strathearn, A. Grandgirard, and T. Kalivas. 2009. Mapping community values for natural capital and ecosystem services. Ecological Economics 68:1301-1315.

82. Reed, M. S., A. Bonn, W. Slee, N. Beharry-Borg, J. Birch, I. Brown, T. P. Burt, D. Chapman, P. J. Chapman, G. D. Clay, S. J. Cornell, E. D. G. Fraser, J. H.

Glass, J. Holdeng, J. A. Hodgson, K. Hubacek, L. B. Irvine, N.Jin, M. J. Kirkby, W. E. Kunin, O. Moore, D. Moseley, C. Prell, M. F. Price, C. H. Quinn, S.

Redpath, C. Reid, S. Stagl, L. C. Stringer, M. Termansen, S. Thorp, W. Towers, and F. Worrall. 2009. The future of the uplands. Land Use Policy 26:S204-S216.

83. Rodríguez, J. P., T. D. Beard, J. R. B. Agard, E. Bennett, S. Cork, G. Cumming, D. Deane, P. Andrew, D. M. Lodge, M. Mutale, G. C. Nelson, G. D. Peterson, T. Ribeiro, B. Tan, and C. Field. 2005. Interactions among Ecosystem Services. Pages 431-448 in S. R. Carpenter, P. L. Pingali, E. M. Bennett, and M. B. Zurek, editors. Millennium Ecosystem Assessment. Ecosystems and human well-being. Findings of the Scenarios Working Group. Island Press, Washington, D.C., USA.

84. Rodríguez, J. P., T. D. Beard, E. M. Bennett, G. S. Cumming, S. J. Cork, J. Agard, A. P. Dobson, and G. D. Peterson. 2006. Trade-offs across Space, Time, and Ecosystem Services. Ecology and Society 11:28.

85. Rönnbäck, P., N. Kautsky, L. Pihl, M. Troell, T. Söderqvist, and S. Tore. 2007. Ecosystem Goods and Services from Swedish Ecosystem and Habitats: Coastal Identification, Valuation and Implications of Ecosystem Shifts. Ambio 36:534544.

86. Schaich, H., C. Bieling, and T. Plieninger. 2010. Linking Ecosystem Services with Cultural Landscape Research. Gaia 19:269 - 277.

87. Schröter, D. 2005. Vulnerability to Changes in Ecosystem Services. Working Paper No. 10, Center for International Development at Harvard University, Cambridge, Massachusetts, USA.

88. Seppelt, R., B. Fath, B. Burkhard, J. L. Fisher, A. Grêt-Regamey, S. Lautenbach, P. Pert, S. Hotes, J. Spangenberg, P. H. Verburg, and A. P. E. Van Oudenhoven.
Journal article

Journal article

MA chapter

Journal article

Journal article

Journal article

Working paper

Journal article 
2012. Form follows function? Proposing a blueprint for ecosystem service assessments based on reviews and case studies. Ecological Indicators 21:145154.

89. Skaggs, R. 2008. Ecosystem Services and Western U.S. Rangelands. Choices 23:37-41.

90. Smart, S. M., L. C. Maskell, and P. Henrys. 2010. Appropriate diversity: a "cultural" ecosystem service. An Integrated Assessment of Countryside Survey data to investigate Ecosystem Services in Great Britain.

91. Smith, N., R. Deal, J. Kline, D. Blahna, T. Patterson, T. A. Spies, and K. Bennett. 2011. Ecosystem Services as a Framework for Forest Stewardship: Deschutes National Forest Overview. General Technical Report PNW-GTR-852, United States Department of Agriculture Forest Service.

92. Swinton, S. M., F. Lupi, G. P. Robertson, and S. K. Hamilton. 2007. Ecosystem services and agriculture: Cultivating agricultural ecosystems for diverse benefits. Ecological Economics 64:245-252.

93. Tielbörger, K., A. Fleischer, L. Menzel, J. Metz, and M. Sternberg. 2010. The aesthetics of water and land: a promising concept for managing scarce water resources under climate change. Philosophical Transactions of the Royal Society 368:5323-5337.

94. Tompkins, J.-M., E. J. Hearnshaw, and R. Cullen. 2011. Evaluating the sustainability of impounded river systems and the cost-effectiveness of dam projects: An ecosystem services approach. $55^{\text {th }}$ Annual Australian Agricultural and Resource Economics Society National Conference, Melbourne, Victoria, Australia.

95. Turner, K. 2010. A Pluralistic Approach to Ecosystem Services Evaluation. CSERGE Working Paper EDM 10-07. The Centre for Social and Economic Research on the Global Environment (CSERGE), Norwich, UK.

96. Tzoulas, K., and P. James. 2010. Peoples' use of, and concerns about, green space networks: A case study of Birchwood, Warrington New Town, UK. Urban Forestry \& Urban Greening 9:121-128.

Journal article

Report

Report

Journal article

Journal article

Full paper presented at conferences

Working paper

Journal article 
97. Vandewalle, M., M. T. Sykes, P. A. Harrison, G. W. Luck, P. Berry, R. Bugter, T.P. Dawson, C.K. Feld, R. Harrington, J.R. Haslett, D. Hering, K.B. Jones, R.

Report Jongman, S. Lavorel, P. Martins da Silva, M. Moora, J. Paterson, M.D.A. Rounsevell, L. Sandin, J. Settele, J. P. Sousa, and M. Zobel. 2008. Review paper on concepts of dynamic ecosystems and their services - RUBICODE. Funded under the European Commission Sixth Framework Programme.

98. Vejre, H., F. S. Jensen, and B. J. Thorsen. 2010. Demonstrating the importance of intangible ecosystem services from peri-urban landscapes. Ecological Complexity 7:338-348.

99. Viglizzo, E. F., J. M. Paruelo, P. Laterra, and E. G. Jobbágy. 2012. Ecosystem service evaluation to support land-use policy. Agriculture, Ecosystems \& Environment 154:78-84.

100. Vihervaara, P., T. Kumpula, A. Tanskanen, and B. Burkhard. 2010. Ecosystem services-A tool for sustainable management of human-environment systems. Case study Finnish Forest Lapland. Ecological Complexity 2:410-420.

101. Vihervaara, P., A. Marjokorpi, T. Kumpula, M. Walls, and M. Kamppinen. 2012. Ecosystem services of fast-growing tree plantations: A case study on integrating social valuations with land-use changes in Uruguay. Forest Policy and Economics 14:58-68.

102. Vilà, M., C. Basnou, P. Pyšek, M. Josefsson, P. Genovesi, S. Gollasch, W. Nentwig, S. Olenin, A. Roques, D. Roy, and P. E. Hulme. 2010. How well do we understand the impacts of alien species on ecosystem services? A pan-European, cross-taxa assessment. Frontiers in Ecology and the Environment 8:135-144.

103. Voora, V., and S. Barg. 2008. Pimachiowin Aki World Heritage Project Area Ecosystem Services Valuation Assessment. International Institute for Sustainable Development (IISD).

104. Wallace, K. J. 2007. Classification of ecosystem services: Problems and solutions. Biological Conservation 39:235-246.

105. Wang, Z., J. I. Nassauer, R. W. Marans, and D. G. Brown. 2012. Different Types of Open Spaces and Their Importance to Exurban Homeowners. Society

Journal article

Journal article

Journal article

Journal article

Journal article

Report

Journal article

Journal article 
\& Natural Resources 25:368-385.

106. Whitfield, S., M. Reed, K. Thomson, M. Christie, L. C. Stringer, C. H. Quinn, R. Anderson, A. Moxey, and K. Hubacek. 2011. Managing Peatland Ecosystem Services: Current UK Policy and Future Challenges in a Changing World. Scottish Geographical Journal 127:209-230.

107. Zander, K. K., S. T. Garnett, and A. Straton. 2010. Trade-offs between development, culture and conservation - Willingness to pay for tropical river management among urban Australians. Journal of Environmental Management

Journal article 91:2519-2528. 


\section{Appendix 2}

Table A2.1. Set of questions asked for every paper reviewed. The column "Cluster analysis" indicates whether the question was used to inform the cluster analysis. When information relating to some of the questions was not provided or did not apply to the text of the publication, the response was classified as "not applicable" with the exception of: Q1, Q2, Q3, Q16, Q17, Q19, Q20.

Question

Response categories

Based on

Cluster

analysis

1 Year of publication

2 Percentage of the text length of the paper dedicated to CES without bibliography pages

3 Type of paper $^{\dagger}$

4 Discipline of first author

\section{Supplier of CES ${ }^{\dagger}$}

6 Country of the case study ${ }^{\dagger}$
$<5 \%$

$5-25 \%$

$25-50 \%$

$50-75 \%$

$>75 \%$

Case-study

Conceptual

Review

Biodiversity conservation and ecology

Environmental management and policy making

Others (Geography, Social sciences,

Engineering, Chemistry)

Agriculture and forestry

Economics

Specific geographical area

Specific type of ecosystem(s)

Stocks of natural assets

One or multiple species
Schaich et al.

2010

No

No

Schaich et al. Yes

2010

Vejre et al. Yes 2010

Constanza et Yes al. 2011

Vihervaara

2010b

Seppelt et al. No 
7 Scale of the case study ${ }^{\dagger}$

\section{Category of CES addressed by the} publications $^{\dagger}$

9 Is ecotourism considered/debated within the

CES category?

10 Methodology for CES

identification/elicitation

11 Driver of CES change publications are dealing with ${ }^{\dagger}$
Local 0-999 km²

Landscape 1000-9999 km²

Regional 10000-99999 km²

National or global $>100000 \mathrm{~km}^{2}$

Recreation and ecotourism

Aesthetic values

Spiritual and religious values

Educational values

Cultural heritage values

Bequest intrinsic and existence

Inspiration

Sense of place

Knowledge systems

Social relations

Cultural diversity

Yes

No

Quantitative

Qualitative

Mixed

Indirect drivers of change:

Socio-political

Economic

Science and technology

Demographic and culture and religion

Direct drivers of change:
Vihervaara

2010b

Constanza et Yes

al. 2011

MA 2005

Yes

Burkhard et al.

2012

Raymond et al.

2009

Gee and

Burkhard 2010

TEEB 2010a No

Schaich et al. Yes 2010

MA 2005, p. No 64-67

MA 2005, p. 
12 Does the paper undertake/

conceptualize/mention the economic valuation of CES?

13 Method for economic valuation applied or discussed in relation to $\mathrm{CES}^{\dagger}$

14 Does the paper argue for a non-economic valuation of CES?

15 Does the paper involve/conceptualize involving stakeholders for assessing CES as in participation?

16 Does it link CES to wellbeing or human health?

17 Does the paper undertake or conceptualize mapping of CES?

18 Does it mention/discuss trade-offs between CES and other ES?
Improper management and overexploitation of

$67-68$

Resources

Land use/cover change

Climate change

Pollution

Invasive species

Yes/No

de Groot et al. Yes 2010

Contingent valuation

Market price and cost approaches

Travel cost method

Hedonic pricing

Benefits transfer

Choice experiment

Deliberative valuation

Yes/No

Kumar and

No

Kumar 2008

Sherrouse et

al. 2011

Seppelt et al. Yes

2011

Yes/No

MA 2003

Yes

Yes/No

Yes/No
MA 2005

Constanza et No

al. 2011

Constanza et No

al. 2011

Seppelt et al. 
19 Does it integrate CES in bundles of ES, does Yes/No it discuss/mention bundles?

20 Does the article use at least one reference from landscape ecology literature (in relation to Yes/No $\mathrm{ES})$ ?

$\uparrow$ Response categories to these questions are not mutually exclusive

\$ Response categories to this question are mutually exclusive with the exception of Busch et al. 2012
2011

Raudsepp-

No

Hearne et al.

2010a

Constanza et

al. 2011

Schaich et al. No 